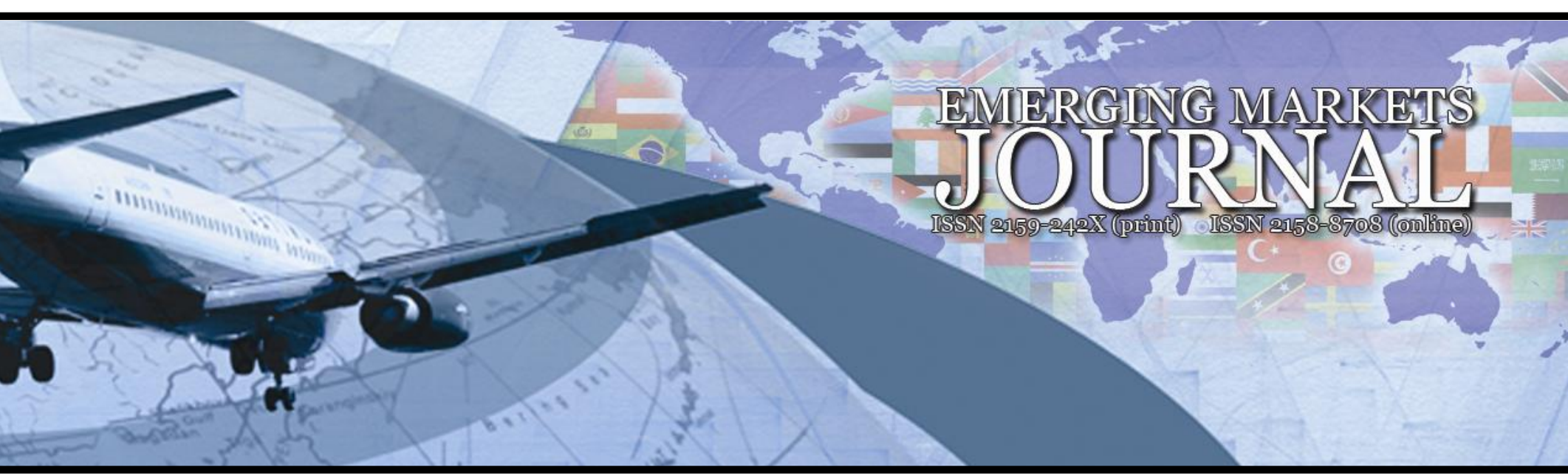

\title{
Impact of Mentoring on Organizational Commitment and Job Satisfaction of Accounting-Finance Academicians Employed in Turkey
}

\section{Dr. Ayşe Tansel Çetin}

Yalova University | e-mail: aysetanselcetin@gmail.com

\section{Dr. Cevdet Kizil}

Yalova University | e-mail: cevdetkizil@yahoo.com

\section{Halil İbrahim Zengin}

Yalova University | e-mail: ibrahim0061@hotmail.com

Volume 3 No 2 (2013) ｜ ISSN 2158-8708 (online) ｜ DOI 10.5195/emaj.2013.40 | http://emaj.pitt.edu |

\section{Abstract}

The primary objective of this paper is to investigate the impact of mentoring on organizational commitment and job satisfaction of accounting-finance academicians employed in Turkey. Survey method is utilized in order to reach this goal and questionnaires are distributed to test the effect of mentoring on Turkish accounting-finance scholars' organizational commitment and job satisfaction. This paper contributes to the literature by pointing out the relationship among mentoring, organizational commitment and job satisfaction, which in turn leads to more efficient mentoring management and necessary measures in Turkish accounting-finance community.

* This paper won the Best Paper Award at 6th Asian Business Research Conference organized by World Academy of Social Sciences. We would like to express our special thanks to the attendants of our sessions and discussants in the 6th Asian Business Research Conference (Bangkok, Thailand) and 8th International Strategic Management Conference (Barcelona, Spain). Especially, the conference Chair Prof. Dr. Zia Haqq deserves additional appreciation with his input, suggestions and academic critics.

Kevwords: accounting, finance, mentoring, organizational commitment, job satisfaction (cc) Br

New articles in this journal are licensed under a Creative Commons Attribution 3.0 United States License.

\section{UILIS D-Sonk}

This journal is published by the University Library System of the University of Pittsburgh as part of its D-Scribe Digital Publishing Program, and is cosponsored by the University of Pittsburgh Press. 


\section{Impact of Mentoring on}

\section{Organizational Commitment}

and Job Satisfaction of

\section{Accounting-Finance}

\section{Academicians Employed in}

\section{Turkey}

\author{
Dr. Ayşe Tansel Çetin \\ Dr. Cevdet Kız1 \\ Halil İbrahim Zengin
}

\section{I.Introduction}

Mentoring at work is gaining importance and attracting attention every passing year. This is mainly because mentoring in the business life brings a number of benefits to organizations for several years (Levinson, Darrow, Klein, Levinson and McKee, 1978; Roche, 1979). For instance job satisfaction, promotion and higher salary payment can be listed as significant benefits of mentoring (Whitely, Dougherty and Dreher, 1991; Dreher and Ash, 1990; Fagenson, 1989; Turban and Dougherty, 1994; Chao, Walz and Gardner, 1992; Whitely and Coetsier, 1993).

Also, mentoring is considered as a key factor in the learning process of protégés and an influential element in the work identity, improvement and self esteem of younger individuals (Levinson, Darrow, Klein, Levinson and McKee, 1978). Mentoring is indeed a tool for the planned career development of protégés and young professionals (Zey, 1984) as well as being a locomotive career source for improving managerial talent (Bernstein and Kaye, 1986; Ragins and Scandura, 1994). Past studies did also investigate the effect of mentoring on women and men protégés' career advancement and revealed significant findings (Tharenou, 2005). Similarly, former research shows that mentoring is in a critical position in terms of career satisfaction, career commitment and turnover intentions (Koberg, Boss and Goodman, 1998; Noe, 1988, Major, Kozlowski, Chao and Gardner, 1995).

Additionally, mentors serve as a bridge enabling information exchange and enhancing knowledge acquisition (Mullen, 1994). Thus, mentors have an eye-catching role in organizational knowledge (Kanter, 1993; Ostroff and Kozlowski, 1993). Besides, mentors are thought to be assisting mechanisms of informational and instrumental social support (Allen, McManus and Russell, 1999). At this point, previous studies prove that employees with mentors learn about the workflow in an organization faster and more efficiently (Ostroff and Kozlowski, 1993; Wilson and Elman, 1990). Another advantage of mentoring is that it fosters job enrichment since the mentor assigns many tasks to protégé through the mentoring process (Hackman and Oldham, 1976). Moreover, mentoring has a key impact in reducing role ambiguity (Sawyer, 1992) and increasing productivity (Silverhart, 1994).

Concerning the accounting environment, mentoring is again very important for the business, clients, employees and other stakeholders. First of all, existence of mentoring in large-scaled public accounting firms provides feedback to protégés as well as improving their relations with customers and strategic partners (Dirsmith et al, 1997).

In regards to academics, role of mentoring should also be noted. According to past research, academic success increases parallel to mentoring, trust and commitment. For instance, former study shows that development of a professional relationship between a supervisor and a doctoral candidate based on specific variables such as trust and commitment fosters successful completion of a doctoral program. (McPhail and Erwee, 2000). Additionally, mentor becomes a role model in the academic environment, provides advice and access to the profession (Blackburn et. al., 1981). A research run in Turkey also supports this statement by focusing on mentoring for early career-stage and young academicians. The mentioned study revealed

Impact of Mentoring on Organizational Commitment and Job Satisfaction of Accounting-Finance Academicians Employed in Turkey 
that research assistants in Anadolu University respected their mentors. However, they had low levels of admiration towards their mentors. Moreover, according to the results of research, friendship factor was not highly received by research assistants. Besides, level of interaction between mentors and research assistants outside the university environment was low. Finally, a great majority of research assistants perceived a mentorprotégé relationship and considered mentoring as a career development tool parallel to the emphasized research (Özkalp, Kırel, Sungur and Cengiz, 2006).

Another research analyzing mentoring in the academic environment showed that mentoring did increase the success level of female assistant professors. Tested mentoring program was found to be effective in increasing the grants received and raising the number of publications (Blau, Currie, Croson and Ginther, 2010). One study investigated the impact of mentoring on turnover ratios and skills of teachers working in New York City. The mentioned study determined strong relationships between measures of mentoring quality and teachers' claims concerning the effect of mentors on their success in the classroom. However, effects on teacher absences, retention and student achievement were lower. Furthermore, time spent working with mentor was significant to improve the teaching skills of teachers (Rockoff, 2008).

Likewise, the impact of mentoring in higher education was studied. This study did also attract attention to the importance of mentoring in academics. According to findings, participants in formal mentoring programs were more productive in terms of publication output compared to nonparticipants. On the other hand, informal mentoring was not found to be effective in mentees' publication performance (Muschallik and Pull, 2012). In addition, another research pointed out that there was no evidence indicating positive outcomes and improvement for female graduate students who had more female faculty members or female dissertation chairs. But, female faculty members had some limited positive effect on female graduate students' graduation periods and completion rates in terms of mentorship (Neumark and Gardecki, 1996).
Despite the numerous listed benefits of mentoring and the presence of a mentor, positive outcomes are not observed in all circumstances since quality of mentorship is also very important. In other words, protégés are expected to experience favorable results with mentors, but this is tightly related to how mentoring is provided (Ragins, Cotton and Miller, 2000).

Originally, the term "mentor" dates back to the ancient era and Greek mythology. It is used to describe a relationship between a younger individual and an older, more experienced individual who assists the younger person to navigate the adult world and the world of work (Allen, Poteet, Eby, Lentz and Lima, 2004).

Definitely, the terms mentor and mentoring have been used frequently since then and there is still a big debate on the most accurate definition of both terms. For example, according to another description of mentoring, it is off-line help by one individual to another in making important transitions in knowledge, work or thinking (Megginson and Clutterbuck, 1995).

One detailed description of mentoring states that, it is an extensive interpersonal exchange between a higher experienced colleague (mentor) and a lower experienced junior colleague (protégé) in which the mentor presents support, direction and feedback concerning career plans and personal improvement (Dalton, Thompson and Price, 1977; Hall, 1976; Levinson, Darrow, Klein, Levinson and McKee, 1978).

There are also short and simple definitions of mentoring, as mentioned in the records of Renaissance time. Mentoring is defined as the commonly accepted technique of educating young people in these records (Wickman, 1997). Another short definition states that mentoring is a improving relationship which involves organizational members of unequal status or, less frequently, peers (Bozionelos, 2004).

The aim and main idea of this research is to investigate the impact of mentoring on the organizational commitment and job satisfaction of accounting-finance academicians working in Turkey. This study was run to answer the following 
research questions: "Does existence of mentoring relationship affect the accounting-finance faculty's organizational commitment?", "Does existence of mentoring relationship affect the accountingfinance faculty's job satisfaction?", "What is the extent and degree of mentoring impact on organizational commitment and job satisfaction?" and "Can we reach to a certain conclusion by measuring the impact of mentoring on organizational commitment and job satisfaction of accounting-finance professors working in Turkey?"

Paper contributes to the fields of accounting and finance, since studies covering the subject of mentoring on academics is limited in Turkey. Moreover, mentoring is currently a leading subject for several researches, which makes it a hot topic for organizations, business sectors, educational institutions and generally the nations. Mentoring relationships do determine the success of all these mentioned stakeholders.

Definitely, this paper also serves as a guide for Turkish universities and accounting-finance instructors. The research is intended to assist related parties better managing their mentoring relationships. This is achieved by presenting a general mentoring interaction observed in the Turkish accounting-finance academy. It is believed that research can motivate accounting-finance academicians and universities in Turkey to take necessary measures for mentoring relationships and come up with more efficient mentoring management systems. Mentoring is especially important in academics since the quality of mentorprotégé relationship determines the improvement and success of academicians. In other words, mentoring is a vital part of academic culture.

Data for this research are gathered from an online questionnaire located at http://www.surveey.com/. The mentioned questionnaire collects data on likert scale basis. Research analyzes individual responses to questionnaire by testing the relationship among independent and dependent variables via running regression and correlation analyses.
Next sections of this research cover the literature review, theoretical research model, measure development, data collection, descriptive statistics, factor analysis, correlation analysis, regression analysis, conclusion and results, limitations and recommendations for future research and references.

\section{Literature Review}

The inter-relationships among mentoring, organizational commitment, organizational justice, job satisfaction and job performance have been researched for decades. Several scientific articles have studied and analyzed the inter-relationships among mentioned dimensions.

Mentoring research did state evidence on links between mentoring relationships and enhanced organizational commitment (Aryee et al, 1996; Scandura, 1997; Baugh, Lankua and Scandura, 1996; Orpen, 1997). One example is researchers showing a relationship between normative commitment and mentorship (Higgins and Kram, 2001). Additional research points out that effective mentoring relationship did require commitment from potential mentors and protégés (Kram, 1988). Other research reported that formal mentoring programs were ineffectual (Covaleski et al, 1998) and informal mentoring programs were more likely to create bonding and commitment compared to formal mentoring programs (Ragins and Cotton, 1999). This finding is supported by an additional work, underlining that personnel with informal mentors were a source for commitment compared to personnel with no mentors (Colarelli and Bishop, 1990) In contrast, another research explained that protégés in formal mentorships were tend to report higher organizational commitment compared to protégés in informal mentorships (Heimann and Pittenger, 1996). Other research also exists which underline the fact that positive mentoring relationships do increase organizational commitment (Siegel and Omer, 1995; Baugh et al, 1996). In relation with mentioned finding, normative and affective commitments are 
determined to be positively correlated (Allen and Meyer, 1990; Hackett et al., 1992; Meyer et al., 1993).

Studies focusing on the relationship between mentoring and job satisfaction indicated that mentoring relationships did create positive job results in terms of higher job satisfaction (Chao, Waltz and Gardner, 1992; Whitely and Coetsier, 1993; Siegel and Omer 1995; Baugh et al, 1996). Besides, employees with informal mentors were subject for higher job satisfaction compared to employees with no mentors (Fagenson, 1989; Chao, Walz and Gardner, 1992). Research showed that this was the same for personnel with formal mentors since they were also reporting higher job satisfaction compared to personnel with no mentors (Seibert, 1999). In addition to mentioned studies, mentoring relationships were found to help understanding unique contributions for explaining protégés' job satisfaction (Scandura, 1997).

Link between organizational justice and organizational commitment was also explored and it was reported that procedural justice was related to organizational commitment (Masterson et. al, 2000). Also, the relationship between organizational commitment and organizational culture was analyzed in Turkey by implementing the survey method on hotel personnel working in Kuşadası. The research found that normative commitment of hotel personnel as a dimension of organizational commitment was higher compared to emotional commitment and continuance commitment (Çavuş and Gürdoğan, 2008).

Similarly, ties between organizational justice and job satisfaction were examined, reaching to results such as justice distribution was predicting job satisfaction (McFarlin and Sweeney, 1992; Sweeney and McFarlin, 1993) and procedural justice was contributing to job satisfaction in a greater extend compared to distributive justice covering a study of Canadian Armed Forces enlisted personnel (Lind and Tyler, 1988; Lind, Lissak and Mendes, 1983). A parallel study supported this finding by emphasizing that procedural justice was more important than distributive justice in regards to supervisor evaluations by bank employees (McFarlin and
Sweeney, 1992). Other research defended that distributive justice was explaining more variance than procedural justice in estimating commitment and turnover for sales studies (Roberts, Coulson and Chonko, 1999; Brashear, Manolis and Brooks, 2005).

Plus, studies supported that distributive justice and procedural justice were positively correlated with job satisfaction (Alexander and Ruderman, 1987; Lind and Tyler, 1988; McFarlin and Sweeney, 1992). Also, relationship between mentoring and organizational justice was researched and it was found from a sample of Australian managers that protégés received more procedural justice compared to non- protégés. However, no difference concerning distributive justice was observed. The study did also put forward that mentoring functions were positively correlated with perceptions of organizational justice (Scandura, 1997). Another research showed that procedural justice leads to a higher job satisfaction than distributive justice (Lind and Tyler, 1988).

Related research also indicated that organizational commitment and job satisfaction were positively linked to each other (Rasch and Harrell, 1990; Aranya and Ferris, 1984). Plus, in accordance with relative literature, job satisfaction precedes organizational commitment in general (Farkas and Tetrick, 1989; Curry et al, 1986; Bateman and Strasser, 1984).

Another study belonging to the accounting literature did investigate the relationship between organizational commitment and organizational culture in Turkey. Results showed that academicians in Selçuk University of Turkey were emotionally committed to their organization. However, same study also revealed that approximately half of the mentioned academicians had low organizational commitment to their institution (Yüceler, 2009). Moreover, a research was conducted in Turkey to examine the relationship between organizational commitment and job burnout of accountants. This study indicated that a negative correlation did exist between the burnout level and organizational commitment of accountants working in Ankara, Turkey. Same study also found that, as accountants 
start to feel their individual success is getting lower, their organizational commitment becomes weaker (Öztürk, Koçyiğit and Bal, 2011).

Concerning the accounting literature, studies focusing on organizational justice are limited. One study analyzed organizational justice in the sense of budget participation (Libby, 1999; Lindquist, 1995). Additionally, the link between organizational justice and mentoring in public accounting firms was researched (Siegel, Reinstein and Miller, 2001). Besides, the relationship between organizational justice and acceptance of voluntary peer reviews in accounting firms was examined in another study (Ehlen and Welker, 1996). Also, one research conducted on certified public accountants and interns did point out that procedural justice in the context of organizational justice was positively related to job satisfaction. On the other hand, same study stated that procedural justice in the context of organizational justice and intentions to quit were negatively correlated (Özer and Günlük, 2010).

\section{Theoretical Research Model}

Research model of this study has three independent variables, which are career development, social support and role modeling (mentoring variables). Also, the research model includes affective commitment, continuance commitment, normative commitment, professional commitment and job satisfaction as dependent variables. Gender and age are control variables.

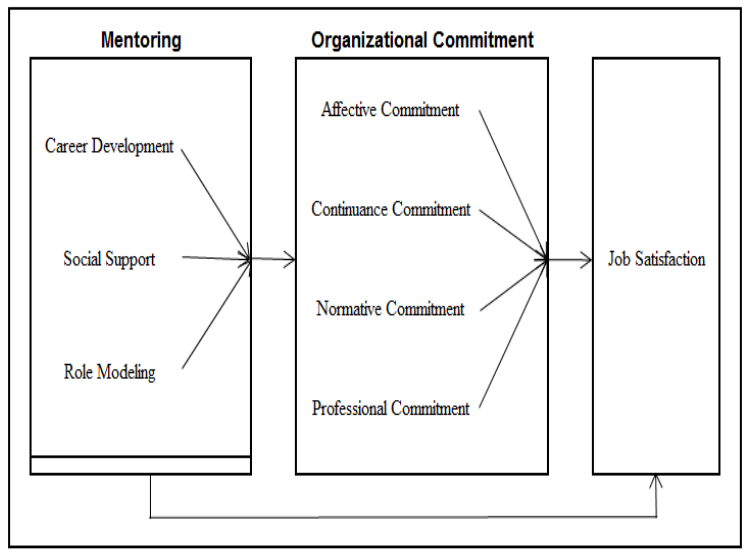

Figure I . Theoretical Research Model

\section{Measure Development}

In this study, we did collect data on a five point Likert scale. Most statements had response categories ranging from 'strongly disagree' (1) to 'strongly agree' (5). Mentoring consists the dimensions of career development, role modeling and social support. In order to measure mentoring, twenty five questions were adapted from Barker, Monks and Buckley 1999 and Viator 2001. Organizational commitment has four subdimensions; affective commitment, continuance commitment, normative commitment, and professional commitment. Also, organizational commitment was assessed by twenty eight items adapted from Bryant (2007). Lastly, job satisfaction was measured by eight questions adapted from Pasework and Viator 2006, and Viator and Pasework 2005. The research also includes questions related to control variables in addition to personal questions for each respondent.

\section{Data Collection}

In order to test the hypothesis, data were collected from accounting and finance academicians in Turkish public and private universities. As a result of the study, 90 responses were gathered from accounting and finance faculty via the questionnaire. Data were assessed through SPSS 13.0 for Windows. We prepared a web link for the questionnaire. The survey questionnaire form was published at www.survey.com and also emails were sent to academicians who were interested in the accounting and finance area.

The characteristics of the sample are are provided on the table below. First of all, $68.9 \%$ of the sample are males and $31.1 \%$ are females. This is equivalent to 62 males and 28 females. $31,1 \%$ of respondents belong to 20-30 age interval, while $40 \%$ are between $31-40$ ages, $21.1 \%$ are between 41-50 ages and $7.8 \%$ are 51 and over. $28.9 \%$ of respondents are married and $71.1 \%$ are single. Also, $43.3 \%$ of academicians taking the questionnaire do not have children. But, $23,3 \%$ have 1 children while $28.9 \%$ have 2 and $4.4 \%$ have 3 children. Concerning the education level, the highest majority belongs to $\mathrm{Ph} . \mathrm{D}$. graduates $(70 \%)$. Then,

Impact of Mentoring on Organizational Commitment and Job Satisfaction of Accounting-Finance Academicians Employed in Turkey 
$23.3 \%$ of respondents have graduate and $6.7 \%$ have undergraduate degrees. $90 \%$ of respondents work in a public university and $8.9 \%$ work in a private university. The remanining $1.1 \%$ represents other respondents who did not want to provide information about this question. $34.4 \%$ of survey takers did work in a different university before in their career, while $58.9 \%$ have never worked in a

Table I. Characteristics of the Sample

\begin{tabular}{|c|c|c|c|}
\hline Characteristics & & Frequency & Percent \\
\hline \multirow[t]{2}{*}{ Gender } & Male & 62 & 68.9 \\
\hline & Female & 28 & 31.1 \\
\hline \multirow[t]{4}{*}{ Age } & $20-30$ & 28 & 31.1 \\
\hline & $31-40$ & 36 & 40 \\
\hline & $41-50$ & 19 & 21.1 \\
\hline & $51+$ & 7 & 7.8 \\
\hline \multirow[t]{2}{*}{ Marital Status } & Married & 64 & 28.9 \\
\hline & Single & 26 & 71.1 \\
\hline \multirow[t]{4}{*}{$\begin{array}{l}\text { Number of } \\
\text { Children }\end{array}$} & No & 39 & 43.3 \\
\hline & 1 & 21 & 23.3 \\
\hline & 2 & 26 & 28.9 \\
\hline & 3 & 4 & 4.4 \\
\hline \multirow[t]{3}{*}{ Education } & Undergraduate & 6 & 6.7 \\
\hline & Graduate & 21 & 23.3 \\
\hline & $\mathrm{PhD}$ & 63 & 70 \\
\hline \multirow{3}{*}{ University Type } & $\begin{array}{c}\text { Public } \\
\text { University }\end{array}$ & 81 & 91 \\
\hline & $\begin{array}{c}\text { Private } \\
\text { University }\end{array}$ & 8 & 9 \\
\hline & Missing & 1 & 1.1 \\
\hline \multirow[t]{3}{*}{ Academic Title } & $\begin{array}{l}\text { Research } \\
\text { Assistant }\end{array}$ & 21 & 23.3 \\
\hline & Lecturer & 16 & 17.8 \\
\hline & Assistant Prof. & 34 & 37.8 \\
\hline
\end{tabular}

separate institution formerly. Rest of the respondents who represent $6.7 \%$ did not answer this question. Moreover, $23.3 \%$ of respondents are research assistants, $17.8 \%$ are lecturers, $37.8 \%$ are assistant professors, $12.2 \%$ are associate professors and $7.8 \%$ are full professors. Finally, $1.1 \%$ of respondents did not answer the mentioned question about their titles.

\begin{tabular}{|c|c|c|c|}
\hline & Associate Prof. & 11 & 12.2 \\
\hline & Full Professor & 7 & 7.8 \\
\hline & Missing & 1 & 1.1 \\
\hline
\end{tabular}

\section{Descriptive Statistics}

Descriptive statistics for the variables used in measuring mentoring, organizational commitment and job satisfaction are presented on Table 2. The means, medians, standard deviations, minimum and maximum values for independent variables as well as dependent variables are also shown on the mentioned table.

Table 2. Descriptive Statistics for Mentoring, Organizational Commitment and Job Satisfaction

\begin{tabular}{|c|c|c|c|c|c|}
\hline & Mean & Median & Std. Dev. & Min. & Max. \\
\hline $\begin{array}{c}\text { Career } \\
\text { Develop } \\
\text { ment }\end{array}$ & 2.963 & 3 & 1.176 & 1 & 5 \\
\hline $\begin{array}{c}\text { Role } \\
\text { Modeling }\end{array}$ & 3.090 & 3.286 & 1.235 & 1 & 5 \\
\hline $\begin{array}{c}\text { Social } \\
\text { Support }\end{array}$ & 2.648 & 2.667 & 1.119 & 1 & 5 \\
\hline
\end{tabular}




\begin{tabular}{|c|c|c|c|c|c|}
\hline $\begin{array}{c}\text { Affective } \\
\text { Commit } \\
\text { ment }\end{array}$ & 3.380 & 3.5 & 1.036 & 1 & 5 \\
\hline $\begin{array}{c}\text { Continua } \\
\text { nce } \\
\text { Commit } \\
\text { ment }\end{array}$ & 2.931 & 3 & 0.866 & 1 & 5 \\
\hline $\begin{array}{c}\text { Normati } \\
\text { ve } \\
\text { Commit } \\
\text { ment }\end{array}$ & 2.966 & 3 & 0.910 & 1 & 5 \\
\hline
\end{tabular}

\section{Factor Analysis}

In order to determine the factor structure of variables, we conducted an exploratory factor analysis with Varimax rotation. This study had factor analysis separately for variables. The results of mentoring variables factor analysis revealed a three-factor structure as expected, which are career development, role modeling, social support. Total variance explained by the mentioned three factors was $80,41 \%$.

Four factors were obtained as a result of organizational variables factor analysis, which are affective commitment, continuance commitment, normative commitment and professional commitment. Total variance explained by the emphasized four factors is $72,184 \%$.

We conducted an exploratory factor analysis for the job satisfaction variable. One factor was obtained as a result of dependent variables factor analysis, which is job satisfaction. The total variance explained by emphasized one factors was $56,465 \%$. The factor loadings supported the internal consistency, since all factor loadings are greater than 0.3 (Kim et al, 2004 and Aydin et. al 2007, Tansel Cetin et al, 2012).

In addition, research used the Cronbach's alpha coefficient for reliability analysis. Cronbach's alpha, a measure for testing the internal consistency or reliability of a set of two or more scale indicators (Cronbach, 1951), was computed for each set of

\begin{tabular}{|c|c|c|c|c|c|}
\hline $\begin{array}{c}\text { Professio } \\
\text { nal }\end{array}$ & 4.259 & 4.333 & 0.729 & 2 & 5 \\
$\begin{array}{c}\text { Commit } \\
\text { ment }\end{array}$ & & 3.8 & 0.668 & 2.2 & 5 \\
\hline $\begin{array}{c}\text { Job } \\
\text { Satisfacti } \\
\text { on }\end{array}$ & 3.767 & 3.2 & & \\
\hline
\end{tabular}

measurements. The reliability coefficients for career development, role modeling, social support, affective commitment, continuance commitment, normative commitment, professional commitment and job satisfaction were 0.96, 0.92, 0.97, 0.94, $0.83,0.82,0.62,0.80$ respectively. All of the Cronbach's alpha values were greater than the recommended level of 0.60 by Nunnally, 1978 . (Nunnaly 1978). This rate is accepted to be sufficiently reliable in the literature. This research

also used the The Kaiser-Meyer-Olkin (KMO) to measure the sampling adequacy and to show that factor analysis is valid. In other words, the KaiserMeyer-Olkin (KMO) is a test, which measures if the sample size is sufficient. Mentoring, organizational commitment and job satisfaction's variables' KMO's measure of sampling adequacy were $0.94,0.81$ and 0.74 . These ratios are accepted in the literature. The ratios showed that, the sample size is sufficient to do factor analysis. According to literature, KMO must be greater than 0.60 (Norusis, 1993; Hair et al., 1998). In this case, sample size is appropriate for factor analysis. Besides, the initial requirement to run a factor analysis is the existence of some relationship among variables. Related with this, the Barlett test indicates whether there is an adequate relationship among variables. If the $p$ value of Barlett test is lower than 0,05 significance level, then there is an adequate level of relationship among variables to do factor analysis. Since the all $\mathrm{p}$ value in this research were 0,000 , variables are suitable for analysis.

Impact of Mentoring on Organizational Commitment and Job Satisfaction of Accounting-Finance Academicians Employed in Turkey 
Table 3. Results of the Mentoring Factor Analysis

\begin{tabular}{|c|c|c|}
\hline & $\begin{array}{c}\text { Factor } \\
\text { Loadings }\end{array}$ & $\begin{array}{c}\text { Cronbach } \\
\alpha\end{array}$ \\
\hline Career Development & & 0.96 \\
\hline $\begin{array}{c}\text { My mentor did show a real } \\
\text { and special care for my } \\
\text { career }\end{array}$ & 0,737 & \\
\hline $\begin{array}{l}\text { My mentor included me as } \\
\text { a team member for } \\
\text { important tasks }\end{array}$ & 0,683 & \\
\hline $\begin{array}{l}\text { My mentor did provide me } \\
\text { special training and gave } \\
\text { me advices concerning my } \\
\text { profession }\end{array}$ & 0,820 & \\
\hline $\begin{array}{l}\text { My mentor gave me } \\
\text { recommendations for } \\
\text { promotion and advancing } \\
\text { opportunities in my career }\end{array}$ & 0,640 & \\
\hline $\begin{array}{c}\text { My mentor assisted me in } \\
\text { coordinating my } \\
\text { professional goals }\end{array}$ & 0,757 & \\
\hline $\begin{array}{l}\text { My mentor spared some } \\
\text { serious time and showed a } \\
\text { real interest in my career }\end{array}$ & 0,783 & \\
\hline $\begin{array}{l}\text { My mentor supported me to } \\
\text { have responsibilities in the } \\
\text { university, which did } \\
\text { strengthen my relations } \\
\text { with managers of the } \\
\text { faculty }\end{array}$ & 0,754 & \\
\hline $\begin{array}{l}\text { My mentor supported me } \\
\text { by assigning tasks, which } \\
\text { did teach me new } \\
\text { capabilities and improved } \\
\text { my expertise in a spcial } \\
\text { field }\end{array}$ & 0,792 & \\
\hline Role Modeling & & 0.92 \\
\hline
\end{tabular}

\begin{tabular}{|c|c|c|}
\hline $\begin{array}{l}\text { I try to model my behaviors } \\
\text { parallel to my mentor }\end{array}$ & 0,670 & \\
\hline $\begin{array}{c}\text { I admire my mentor's talent } \\
\text { in motivating other } \\
\text { professionals }\end{array}$ & 0,716 & \\
\hline $\begin{array}{l}\text { I respect my mentor's } \\
\text { knowledge on his } \\
\text { profession }\end{array}$ & 0,800 & \\
\hline $\begin{array}{l}\text { I respect my mentor's talent } \\
\text { of training and developing } \\
\text { other professionals }\end{array}$ & 0,810 & \\
\hline $\begin{array}{l}\text { I try to model my mentor's } \\
\text { behaviors and do my best to } \\
\text { display similar actions }\end{array}$ & 0,769 & \\
\hline $\begin{array}{l}\text { I respect my mentor and } \\
\text { admire him/her }\end{array}$ & 0,803 & \\
\hline $\begin{array}{l}\text { When I have a similar } \\
\text { position to my mentor in } \\
\text { the future, I will show } \\
\text { effort to be like him/her }\end{array}$ & 0,731 & \\
\hline Social Support & & 0.97 \\
\hline $\begin{array}{l}\text { I share my personal } \\
\text { problems with my mentor }\end{array}$ & 0,677 & \\
\hline $\begin{array}{l}\text { I engage in social activities } \\
\text { and chat with my mentor } \\
\text { after work }\end{array}$ & 0,844 & \\
\hline $\begin{array}{l}\text { I consider my mentor as a } \\
\text { friend }\end{array}$ & 0,757 & \\
\hline $\begin{array}{l}\text { I frequently go to lunch } \\
\text { with my mentor }\end{array}$ & 0,688 & \\
\hline $\begin{array}{l}\text { My mentor encouraged me } \\
\text { to talk straight about } \\
\text { concerns and fears, which } \\
\text { affect my performance } \\
\text { negatively }\end{array}$ & 0,537 & \\
\hline $\begin{array}{c}\text { My mentor showed } \\
\text { empathy for the concerns } \\
\text { and fears I shared with } \\
\text { him/her }\end{array}$ & 0,566 & \\
\hline
\end{tabular}


4. Organizational Commitment and Job Satisfactions' Factor Analysis

\begin{tabular}{|c|c|c|}
\hline & $\begin{array}{c}\text { Factor } \\
\text { Loadings }\end{array}$ & $\begin{array}{c}\text { Cronbach } \\
\alpha\end{array}$ \\
\hline Affective Commitment & & 0.94 \\
\hline $\begin{array}{l}\text { I feel very committed to my } \\
\text { university }\end{array}$ & 0,915 & \\
\hline $\begin{array}{c}\text { I will be very happy to } \\
\text { spend the rest of my career } \\
\text { in this university }\end{array}$ & 0,856 & \\
\hline $\begin{array}{c}\text { This university has a great } \\
\text { personal and emotional } \\
\text { meaning for me }\end{array}$ & 0,834 & \\
\hline $\begin{array}{c}\text { I feel like "part and member } \\
\text { of the family" in this } \\
\text { university }\end{array}$ & 0,906 & \\
\hline $\begin{array}{l}\text { I am happy to discuss and } \\
\text { mention my university with } \\
\text { others, who are not a } \\
\text { member of my institution }\end{array}$ & 0,880 & \\
\hline $\begin{array}{l}\text { I really consider and feel } \\
\text { the problems of my } \\
\text { university like they are my } \\
\text { own problems }\end{array}$ & 0,821 & \\
\hline Continuance Commitment & & 0.83 \\
\hline $\begin{array}{l}\text { It would be very difficult } \\
\text { for me to leave my } \\
\text { organization now, even if I } \\
\text { wanted to do this. }\end{array}$ & 0,508 & \\
\hline $\begin{array}{l}\text { If I decide to leave my } \\
\text { university now, my life will } \\
\text { probably be affected } \\
\text { negatively to a large extent }\end{array}$ & 0,796 & \\
\hline $\begin{array}{l}\text { Continuing to work in my } \\
\text { university right now is a } \\
\text { result of my needs and } \\
\text { necessisities, as much as my } \\
\text { desires. }\end{array}$ & 0,775 & \\
\hline
\end{tabular}

\begin{tabular}{|c|c|c|}
\hline $\begin{array}{l}\text { I believe that I have very } \\
\text { limited options for } \\
\text { considering to leave my } \\
\text { university }\end{array}$ & 0,781 & \\
\hline $\begin{array}{l}\text { One of the few negative } \\
\text { outcomes of leaving my } \\
\text { university would be that, I } \\
\text { could be short of } \\
\text { alternatives }\end{array}$ & 0,785 & \\
\hline $\begin{array}{l}\text { One of the main reasons for } \\
\text { me to continue working in } \\
\text { this university is that, } \\
\text { resigning will require so } \\
\text { much personal sacrifice. } \\
\text { Another university may not } \\
\text { generally provide me the } \\
\text { same benefits and } \\
\text { advantages I have in my } \\
\text { current university }\end{array}$ & 0,557 & \\
\hline Professional Comitment & & 0.82 \\
\hline $\begin{array}{l}\text { I definitely want and target } \\
\text { an ideal career for me in } \\
\text { this profession }\end{array}$ & 0,760 & \\
\hline $\begin{array}{l}\text { If I had a chance to go over } \\
\text { everything in my life, I } \\
\text { would choose my } \\
\text { profession once again. }\end{array}$ & 0,898 & \\
\hline $\begin{array}{l}\text { I recommend others a career } \\
\text { in my profession }\end{array}$ & 0,848 & \\
\hline Normative Commitment & & 0.62 \\
\hline $\begin{array}{l}\text { I was taught to believe that, } \\
\text { being commited and loyal } \\
\text { to an institution is important } \\
\text { and valuable. }\end{array}$ & 0,798 & \\
\hline $\begin{array}{l}\text { It was much better in those } \\
\text { days, when people spent the } \\
\text { majority of their career in a } \\
\text { single university }\end{array}$ & 0,826 & \\
\hline Job Satisfaction & & 0.80 \\
\hline
\end{tabular}

Impact of Mentoring on Organizational Commitment and Job Satisfaction of Accounting-Finance Academicians Employed in Turkey 


\begin{tabular}{|c|c|c|}
\hline $\begin{array}{c}\text { I am very happy with my } \\
\text { current tasks and } \\
\text { responsibilities }\end{array}$ & 0,774 & \\
\hline $\begin{array}{c}\text { My current job and } \\
\text { responsibilities are very } \\
\text { parallel to the ideal jobs and } \\
\text { reponsibilities in my mind }\end{array}$ & 0,901 & \\
\hline $\begin{array}{c}\text { My currently tasks and } \\
\text { responsibilities are pretty } \\
\text { similar to the desired } \\
\text { profession I had in my mind } \\
\text { when choosing this career }\end{array}$ & 0,880 & \\
\hline $\begin{array}{c}\text { My profession is suitable } \\
\text { for my talents }\end{array}$ & 0,538 & \\
\hline $\begin{array}{c}\text { Generally, I really love my } \\
\text { profession }\end{array}$ & 0,586 & \\
\hline
\end{tabular}

Table 5. Correlation Analysis

\begin{tabular}{|c|c|c|c|c|c|c|c|c|}
\hline & 1 & 2 & 3 & 4 & 5 & 6 & 7 & 8 \\
\hline 1.Career Development & 1 & & & & & & & \\
\hline 2Role Modeling & $0.8333^{* *}$ & 1 & & & & & & \\
\hline 3.Social Support & $0.796^{* *}$ & $0.813^{*}$ & 1 & & & & & \\
\hline 4.Affective Commitment & $0.288 * x$ & $0.452 *$ & $0.342^{* *}$ & 1 & & & & \\
\hline 5Continuance Commitmen & 0.124 & 0.161 & 0.167 & 0.101 & 1 & & & \\
\hline 6. Nomative Commitment & $0.378 *$ & $0.390^{*}$ & $0.357^{7 *}$ & $0.290 *$ & $0.228 *$ & 1 & & \\
\hline 7.Professional Commitment & $0.281 * *$ & $0.323 *$ & $0.252^{*}$ & 0.162 & -0.137 & 0.105 & 1 & \\
\hline 8.Job Satisfaction & 0.084 & 0.201 & 0.111 & $0.408 * x$ & 0.076 & 0.022 & $0.389 *$ & 1 \\
\hline
\end{tabular}

**Correlation is significant at the 0.01 level (2tailed),

*Correlation is significant at the 0.05 level (2tailed).

\section{Regression Analysis}

The purpose of this article is to investigate the effects of mentoring (career development, role modeling and social support) on both organizational commitment (affective commitment, continuance commitment, normative commitment and professional commitment) and job satisfaction. Also, we did investigate the effect of organizational commitment on the job satisfaction. We did add

\section{Correlation Analysis}

In order to test the relationship among variables, we conducted Pearson correlation analysis for this research. Results of correlation analysis showed that, career development, role modeling, social support, affective commitment, normative commitment and professional commitment were positively related to each other. Social support and professional commitment were positively related to job satisfaction. Moreover, other variables (career development, role modeling,

social support, continuance commitment, and normative commitment) were not related to job satisfaction. The results of Pearson correlation analysis are displayed on Table 5.

gender and age to the model as control variables. In order to test the effect of independent variables on dependent variables, regression analysis was conducted using the SPSS 13.0 statistical package program. We developed three main regression models in order to test hypotheses in our study. Regression models are as follows:

Organizational Commitment $=\beta_{0}+\beta_{1} *$ Career development $+\beta_{2} *$ Role Modeling $+\beta_{3} *$ Social support $+\beta_{4} *$ Gender $+\beta_{5} *$ Age $+e$

Job satisfaction $=\beta_{0}+\beta_{1}^{*}$ Career development $+\beta_{2} *$ Role Modeling $+\beta_{3} *$ Social support $+\beta_{4} *$ Gender $+\beta_{5} *$ Age $+e$

Job satisfaction $=\beta_{0}+\beta_{1} *$ Affective commitment + $\beta_{2} *$ Continuance commitment $+\beta_{3} *$ Normative commitment $+\beta_{4} *$ Professional commitment $+\beta_{5} *$ Gender $+\beta_{6} *$ Age $+e$ 
Table 6. The Effect of Mentoring on Affective Commitment

\begin{tabular}{|c|c|c|c|c|c|}
\hline & $\begin{array}{c}\text { Dependent } \\
\text { variable: } \\
\text { Affective } \\
\text { Commitmen }\end{array}$ & & & & $\begin{array}{l}\text { earity } \\
\text { tics }\end{array}$ \\
\hline $\begin{array}{l}\text { Independen } \\
\text { t variables }\end{array}$ & $\beta$ & $t$ & Sig. & $\begin{array}{c}\text { Tolera } \\
\text { nce }\end{array}$ & VIF \\
\hline $\begin{array}{c}\text { 1.Career } \\
\text { Developme } \\
\text { nt }\end{array}$ & 0.293 & 3.039 & $\begin{array}{c}0.003 * \\
* *\end{array}$ & 0.861 & 1.162 \\
\hline Gender & -0.026 & -0.107 & 0.915 & 0.868 & 1.151 \\
\hline Age & 0.021 & 1.720 & $0.089 *$ & 0.929 & 1.076 \\
\hline F & $3.704 * * *$ & & & & \\
\hline Adj. R2 & 0.084 & & & & \\
\hline $\begin{array}{c}\text { 2.Role } \\
\text { Modeling }\end{array}$ & 0.400 & 4.823 & $\begin{array}{c}0.000 * \\
* *\end{array}$ & 0.926 & 1.080 \\
\hline Gender & -0.040 & -0.182 & 0.856 & 0.911 & 1.098 \\
\hline Age & 0.017 & 1.503 & 0.137 & 0.951 & 1.052 \\
\hline $\mathrm{F}$ & $8.283 * * *$ & & & & \\
\hline Adj. R2 & 0.199 & & & & \\
\hline $\begin{array}{l}\text { 3.Social } \\
\text { Support }\end{array}$ & 0.331 & 3.460 & $\begin{array}{c}0.001 * \\
* *\end{array}$ & 0.937 & 1.067 \\
\hline Gender & 0.018 & 0.075 & 0.940 & 0.909 & 1.100 \\
\hline Age & 0.018 & 1.470 & 0.145 & 0.953 & 1.050 \\
\hline F & $4.633^{* * *}$ & & & & \\
\hline Adj. R2 & 0.109 & & & & \\
\hline $\begin{array}{c}\text { 4.Career } \\
\text { Developme } \\
\text { nt }\end{array}$ & -0.181 & -1.061 & 0.292 & 0.241 & 4.154 \\
\hline $\begin{array}{c}\text { Role } \\
\text { Modeling }\end{array}$ & 0.542 & 3.363 & $\begin{array}{c}0.001 * \\
* *\end{array}$ & 0.247 & 4.042 \\
\hline $\begin{array}{c}\text { Social } \\
\text { Support }\end{array}$ & -0.006 & -0.037 & 0.970 & 0.285 & 3.504 \\
\hline Gender & 0.015 & 0.067 & 0.947 & 0.871 & 1.148 \\
\hline Age & 0.016 & 1.329 & 0.188 & 0.932 & 1.073 \\
\hline
\end{tabular}

\begin{tabular}{|c|c|c|c|c|c|}
\hline F & $5.206^{* * *}$ & & & & \\
\hline Adj. R2 & 0.193 & & & & \\
\hline
\end{tabular}

*** Coefficient is significant at 0.01 ;

$* *$ Coefficient is significant at 0.05 ;

* Coefficient is significant at 0.10

Model 1 did present the effect of career development, gender and age on affective commitment. The model was statistically significant $(\mathrm{F}=3.704, \mathrm{p}<0.01)$. When model is examined, it was observed that career development $(\boldsymbol{\beta}=0.293 ; \mathrm{p}<0.01)$ and age have a statistically significant effect $(\beta=0.021 ; \mathrm{p}<0.10)$ on the affective commitment. Gender does not have statistically significant effect on the dependent variable. $(\mathrm{p}>0.10)$

Model 2 investigated the effect of role modeling and control variables on the affective commitment. Model's F was statistically significant. $(\mathrm{F}=8.283, \mathrm{p}<0.01)$. Role modeling had a positive and statistically significant effect on affective commitment. When beta coefficients were looked upon, it is understood that the increase in role modeling results to an increase in affective commitment. $(\beta=0.400 ; p<0.01)$. Gender and age did not have a statistically significant effect on affective commitment. ( $p>0.10)$

In the context of model 3, social support, gender and age were independent variables and affective commitment was the dependent variable. Here, social support had a positive and statistically significant effect on the affective commitment. $(\beta=0.331 ; p<0.01) \quad$ Control variables, which were gender and age did not have a statistically significant effect on the affective commitment. $(\mathrm{p}>0.10)$

Model 4 indicated all variables included to the model, which are career development, role modeling, social support, gender and age. The model is statistically significant $(\mathrm{F}=5.206, \mathrm{p}<0.01)$. When beta coefficients of model were taken into consideration, only role modeling had a positive

Impact of Mentoring on Organizational Commitment and Job Satisfaction of Accounting-Finance Academicians Employed in Turkey 
and statistically significant effect on the affective commitment. Career development, social support, gender and age did not have a statistically significant effect on the affective commitment. Concerning model 1,2 and 3, it was observed that, all sub-dimensions of mentoring were significant when they were added to the model separately. However, when sub-dimensions of mentoring were included to the model (model 4) altogether, it is realized that impact of career development and social support no longer exists. This shows us that, when variables are included to the model altogether, they shadow each others' effect.

Table 7. The Effect of Mentoring on Continuance Commitment

\begin{tabular}{|c|c|c|c|c|c|}
\hline & $\begin{array}{c}\text { Dependent } \\
\text { variable: } \\
\text { Continuance } \\
\text { Commitment }\end{array}$ & & \multicolumn{2}{|c|}{$\begin{array}{c}\text { Collinearity } \\
\text { Statistics }\end{array}$} \\
\hline $\begin{array}{c}\text { Independent } \\
\text { variables }\end{array}$ & $\beta$ & $\mathbf{t}$ & Sig. & Tolera & VIF \\
\hline 5.Career \\
Developmen
\end{tabular}

\begin{tabular}{|c|c|c|c|c|c|}
\hline Support & & & & & \\
\hline Gender & 0.341 & 1.793 & $\mathbf{0 . 0 7 6 *}$ & 0.914 & 1.094 \\
\hline Age & -0.032 & -3.213 & $\begin{array}{c}\text { 0.002* } \\
* *\end{array}$ & 0.961 & 1.041 \\
\hline F & $6.369^{* * *}$ & & & & \\
\hline Adj. R2 & 0.155 & & & & \\
\hline 8.Career \\
Developmen
\end{tabular}

*** Coefficient is significant at 0.01 ;

** Coefficient is significant at 0.05 ;

* Coefficient is significant at 0.10

Table above shows the effect of mentoring (career development, role modeling, social support) and control variables (gender and age) on the continuance commitment. Model 5 provides the effect of career development gender and age on the continuance commitment. The model was statistically significant $(\mathrm{F}=5.975 ; \mathrm{p}<0.01)$. Gender had a positive and statistically significant effect while age had a negative statistically significant effect on continuance commitment. Thus, when age went up, continuance commitment went down. Also, research revealed that female academicians had a higher continuance commitment. But, career development did not have a statistically significant effect on continuance commitment. 
Based on model 6, role modeling, gender and age were independent variables and continuance commitment was the dependent variable. Model 6 was statistically significant $(\mathrm{F}=5.551, \mathrm{p}<0.01)$. When coefficients were examined, it was observed that gender had a positive and statistically significant effect on continuance commitment $(\beta=0.349 ; \mathrm{p}<0.10)$ and age had a negative and statistically significant effect $(\beta=-0.031 ; \mathrm{p}<0.01) \quad$ on the dependent variable. However, social support did not have statistically significant effect on the continuance commitment. $(\mathrm{p}>0.10)$

Model 7, which shows the effect of social support. gender and age on the continuance commitment was statistically significant. ( $\mathrm{F}=$ $\mathrm{F}=6.369, \mathrm{p}<0.01)$. Gender and age had a statistically significant effect on continuance commitment. But, gender had a positive effect $(\beta=0.341 ; p<0.10)$ while age had a negative effect ( $\beta=-0.032 ; p<0.01)$ on the continuance commitment. Additionally, social support did not have a statistically significant effect on the dependent variable.

Lastly, for model 8, we investigated the impact of mentoring's all variables (career development, role modeling, and social support) and effect of control variables (gender and age) on the continuance commitment. This model was statistically significant $\quad(\mathrm{F}=3.975, \mathrm{p}<0.01)$. Moreover, gender and age had a statistically significant effect on the dependent variable. But, we found that no dimension of mentoring had an effect on continuance commitment. When variables were included to the model separately, their effect was statistically significant. On the other hand, when all variables were included to the model altogether, their effect did not exist on the dependent variables. We believe that variables shadow each other's impact.
Table 8.The Effect of Mentoring on Normative Commitment

\begin{tabular}{|c|c|c|c|c|c|}
\hline & $\begin{array}{c}\text { Dependent } \\
\text { variable: } \\
\text { Normative } \\
\text { Commitment }\end{array}$ & & & \multicolumn{2}{|c|}{$\begin{array}{c}\text { Collinearity } \\
\text { Statistics }\end{array}$} \\
\hline $\begin{array}{c}\text { Independent } \\
\text { variables }\end{array}$ & $\beta$ & $\mathbf{t}$ & Sig. & $\begin{array}{c}\text { Tolera } \\
\text { nce }\end{array}$ & VIF \\
\hline $\begin{array}{c}\text { 9.Career } \\
\text { Developmen } \\
\mathbf{t}\end{array}$ & 0.257 & 3.171 & $0.002 * * *$ & 0.865 & 1.155 \\
\hline Gender & 0.396 & 1.938 & $0.056 * *$ & 0.873 & 1.146 \\
\hline Age & 0.012 & 1.097 & 0.276 & 0.936 & 1.068 \\
\hline $\mathrm{F}$ & $6.446^{* * *}$ & & & & \\
\hline Adj. R2 & 0.157 & & & & \\
\hline $\begin{array}{c}\text { 10.Role } \\
\text { Modeling }\end{array}$ & 0.256 & 3.450 & $0.001 * * *$ & 0.926 & 1.080 \\
\hline Gender & 0.436 & 2.203 & $0.030 * *$ & 0.911 & 1.098 \\
\hline Age & 0.010 & 0.958 & 0.341 & 0.951 & 1.052 \\
\hline F & $7.122 * * *$ & & & & \\
\hline Adj. R2 & 0.173 & & & & \\
\hline $\begin{array}{l}\text { 11.Social } \\
\text { Support }\end{array}$ & 0.252 & 3.053 & $0.003 * * *$ & 0.931 & 1.074 \\
\hline Gender & 0.454 & 2.262 & $0.026 * *$ & 0.912 & 1.096 \\
\hline Age & 0.009 & 0.863 & 0.390 & 0.954 & 1.049 \\
\hline $\mathrm{F}$ & $6.176^{* * * *}$ & & & & \\
\hline Adj. R2 & 0.150 & & & & \\
\hline 12. & & & & & \\
\hline $\begin{array}{c}\text { Career } \\
\text { Developmen } \\
\mathbf{t}\end{array}$ & 0.072 & 0.467 & 0.642 & 0.241 & 4.154 \\
\hline $\begin{array}{c}\text { Role } \\
\text { Modeling }\end{array}$ & 0.166 & 1.147 & 0.255 & 0.247 & 4.042 \\
\hline $\begin{array}{c}\text { Social } \\
\text { Support }\end{array}$ & 0.049 & 0.330 & 0.742 & 0.285 & 3.504 \\
\hline
\end{tabular}

Impact of Mentoring on Organizational Commitment and Job Satisfaction of Accounting-Finance Academicians Employed in Turkey 


\begin{tabular}{|c|c|c|c|c|c|}
\hline Gender & 0.409 & 2.004 & $\mathbf{0 . 0 4 8} * *$ & 0.871 & 1.148 \\
\hline Age & 0.011 & 1.011 & 0.315 & 0.932 & 1.073 \\
\hline F & $4.305 * * *$ & & & & \\
\hline Adj. R2 & 0.158 & & & & \\
\hline
\end{tabular}

\footnotetext{
*** Coefficient is significant at 0.01 ;

** Coefficient is significant at 0.05 ;

* Coefficient is significant at 0.10
}

Regarding model 9, normative commitment was the dependent variable and career development, gender and age were independent variables. This related model was significant $(\mathrm{F}=6.446, \mathrm{p}<0.01)$. When the model parameters were looked upon, career development and gender were statistically significant on the normative commitment. So, as career development increases, normative commitment also increases. Furthermore, female academicians had a higher normative commitment. Age did not have a statistically significant effect on the normative commitment.

Model 10, which displays the effect of role modeling, gender and age on the normative commitment was statistically significant. $(\mathrm{F}=7.122, \mathrm{p}<0.01)$. Likewise, role modeling and gender had a positive and statistically significant effect on the normative commitment. However, the effect of age on the normative commitment was not statistically significant.

The next model (11) shows the impact of social support, gender and age on the normative commitment. Model's F value was statistically significant $(\mathrm{F}=6.176, \mathrm{p}<0.01)$. Similarly, social support and gender had a positive and statistically significant effect on normative commitment. On the opposite side, age did not have the significant effect on normative commitment. Thus, when social support to academicians by their mentors did increase, their normative commitment also increased.

Last model of the table (model 12) examines the multiple effect of mentoring variables, which are career development, role modeling, and social support. Model's F value is statistically significant $(\mathrm{F}=4.305, \mathrm{p}<0.01)$. Parallel to other models, gender and age were added as control variables to the model. The result of the multiple regression analysis signaled that, when variables were included to the model altogether, their effect did no longer exist. Gender was the only variable that had a statistically significant effect on normative commitment.

Table 9. Effect of Mentoring on Professional Commitment

\begin{tabular}{|c|c|c|c|c|c|}
\hline & \multicolumn{2}{|c|}{$\begin{array}{c}\text { Dependent } \\
\text { variable: } \\
\text { Professional } \\
\text { Commitment }\end{array}$} & & \multicolumn{2}{|c|}{$\begin{array}{c}\text { Collinearity } \\
\text { Statistics }\end{array}$} \\
\hline $\begin{array}{c}\text { Independent } \\
\text { variables }\end{array}$ & $\beta$ & $\mathbf{t}$ & Sig. & $\begin{array}{c}\text { Tolera } \\
\text { nce }\end{array}$ & VIF \\
\hline $\begin{array}{c}\text { 13.Career } \\
\text { Development }\end{array}$ & 0.167 & 2.425 & $0.017 * * * *$ & 0.861 & 1.162 \\
\hline Gender & -0.049 & -0.281 & 0.780 & 0.868 & 1.151 \\
\hline Age & -0.008 & -0.905 & 0.368 & 0.929 & 1.076 \\
\hline $\mathrm{F}$ & $2.756^{* * *}$ & & & & \\
\hline Adj. R2 & 0.056 & & & & \\
\hline $\begin{array}{c}\text { 14.Role } \\
\text { Modeling }\end{array}$ & 0.186 & 2.966 & $0.004 * * *$ & 0.926 & 1.080 \\
\hline Gender & -0.036 & -0.218 & 0.828 & 0.911 & 1.098 \\
\hline Age & -0.008 & -0.881 & 0.381 & 0.951 & 1.052 \\
\hline $\mathrm{F}$ & $3.589 * *$ & & & & \\
\hline Adj. R2 & 0.081 & & & & \\
\hline $\begin{array}{l}\text { 15.Social } \\
\text { Support }\end{array}$ & 0.155 & 2.228 & $0.029 * *$ & 0.937 & 1.067 \\
\hline Gender & -0.006 & -0.033 & 0.974 & 0.909 & 1.100 \\
\hline Age & -0.010 & -1.176 & 0.243 & 0.953 & 1.050 \\
\hline F & $2.442 *$ & & & & \\
\hline Adj. R2 & 0.046 & & & & \\
\hline $\begin{array}{c}\text { 16.Career } \\
\text { Development }\end{array}$ & 0.007 & 0.056 & 0.956 & 0.241 & 4.154 \\
\hline
\end{tabular}




\begin{tabular}{|c|c|c|c|c|c|}
\hline $\begin{array}{c}\text { Role } \\
\text { Modeling }\end{array}$ & 0.188 & 1.532 & 0.129 & 0.247 & 4.042 \\
\hline $\begin{array}{c}\text { Social } \\
\text { Support }\end{array}$ & -0.010 & -0.083 & 0.934 & 0.285 & 3.504 \\
\hline Gender & -0.038 & -0.216 & 0.829 & 0.871 & 1.148 \\
\hline Age & -0.008 & -0.855 & 0.395 & 0.932 & 1.073 \\
\hline F & $2.104 *$ & & & & \\
\hline Adj. R2 & 0.059 & & & & \\
\hline
\end{tabular}

*** Coefficient is significant at 0.01 ;

** Coefficient is significant at 0.05 ;

* Coefficient is significant at 0.10

The table above shows the effect of mentoring (career development, role modeling, and social support), gender and age on the professional commitment. Firstly, model 13 displays career development, gender and age's impact on the professional commitment. The model which was developed for this purpose is found to be statistically significant. $(\mathrm{F}=2.756 ; \mathrm{p}<0,05)$. The effect of career development on the professional commitment was positive and statistically significant. Gender and age had a negative but statistically insignificant effect on the professional commitment.

Model 14 shows the effect of role modeling, gender and age on professional commitment while model 15 indicates the impact of social support, gender and age on the professional commitment. Both models were statistically significant. $(F=3.589, p<0,05 ; F=2.442, p<0,10)$. In model 14 , role modeling and in model 15 social support had a positive statistically significant effect on professional commitment. These two models, gender and age did possess negative but statistically insignificant impact on the professional commitment. Multiple regression analysis reflected that no variable had a statistically significant effect on the professional commitment.
Last model of the table (model 16) examines the multiple effect of mentoring variables (career development, role modeling, and social support) on professional commitment. Models $\mathrm{F}$ value is statistically significant $(\mathrm{F}=2.104, \mathrm{p}<0.10)$. The results of multiple regression analysis signal that when variables are included to the model altogether, their effect no longer exists. We believe that variables shadow each other's impact.

Table 10. The effect of Organizational Commitment on Job Satisfaction

\begin{tabular}{|c|c|c|c|c|c|}
\hline & \multicolumn{2}{|l|}{$\begin{array}{c}\text { Dependent } \\
\text { variable: } \\
\text { Job } \\
\text { Satisfaction }\end{array}$} & & \multicolumn{2}{|c|}{$\begin{array}{c}\text { Collinearity } \\
\text { Statistics }\end{array}$} \\
\hline $\begin{array}{c}\text { Independent } \\
\text { variables }\end{array}$ & $\beta$ & $\mathbf{t}$ & Sig. & Tolerance & VIF \\
\hline $\begin{array}{l}\text { 17.Affective } \\
\text { Commitment }\end{array}$ & 0,248 & 3,805 & $\begin{array}{c}0,000 * * \\
*\end{array}$ & 0,961 & 1,041 \\
\hline Gender & $-0,063$ & $\begin{array}{c}- \\
0,430\end{array}$ & 0,669 & 0,936 & 1,069 \\
\hline Age & 0,012 & 1,479 & 0,143 & 0,917 & 1,091 \\
\hline F & $6,339 * * *$ & & & & \\
\hline Adj. R2 & 0,165 & & & & \\
\hline $\begin{array}{l}\text { 18. Continuanc } \\
\text { e Commitment }\end{array}$ & 0,154 & 1,720 & 0,089* & 0,829 & 1,206 \\
\hline Gender & $-0,060$ & $\begin{array}{c}- \\
0,377\end{array}$ & 0,707 & 0,908 & 1,101 \\
\hline Age & 0,025 & 2,743 & $\begin{array}{c}0,008 * * \\
*\end{array}$ & 0,856 & 1,168 \\
\hline F & $2,860 * *$ & & & & \\
\hline Adj. R2 & 0,063 & & & & \\
\hline $\begin{array}{l}\text { 19.Normative } \\
\text { Commitment }\end{array}$ & 0,017 & 0,200 & 0,842 & 0,921 & 1,086 \\
\hline Gender & $-0,010$ & $\begin{array}{c}- \\
0,058\end{array}$ & 0,954 & 0,878 & 1,139 \\
\hline Age & 0,018 & 2,141 & $\mathbf{0 , 0 3 5} * *$ & 0,949 & 1,054 \\
\hline
\end{tabular}

Impact of Mentoring on Organizational Commitment and Job Satisfaction of Accounting-Finance Academicians Employed in Turkey 


\begin{tabular}{|c|c|c|c|c|c|}
\hline F & 1,645 & & & & \\
\hline Adj. R2 & 0,023 & & & & \\
\hline $\begin{array}{l}\text { 20.Professional } \\
\text { Commitment }\end{array}$ & 0,389 & 4,344 & $\begin{array}{c}0,000 * * \\
*\end{array}$ & 0,976 & 1,024 \\
\hline Gender & $-0,050$ & $\begin{array}{c}- \\
0,351\end{array}$ & 0,727 & 0,942 & 1,062 \\
\hline Age & 0,021 & 2,718 & $\begin{array}{c}0,008 * * \\
*\end{array}$ & 0,937 & 1,067 \\
\hline F & $8,082^{* * * *}$ & & & & \\
\hline Adj. R2 & 0,202 & & & & \\
\hline $\begin{array}{l}\text { 21.Affective } \\
\text { Commitment }\end{array}$ & 0,218 & 3,525 & $\begin{array}{c}0,001 * * \\
*\end{array}$ & 0,847 & 1,180 \\
\hline $\begin{array}{l}\text { Continuance } \\
\text { Commitment }\end{array}$ & 0,212 & 2,698 & $\begin{array}{c}0,009 * * \\
*\end{array}$ & 0,754 & 1,326 \\
\hline $\begin{array}{c}\text { Normative } \\
\text { Commitment }\end{array}$ & $-0,127$ & $\begin{array}{c}- \\
1,775\end{array}$ & 0,080* & 0,819 & 1,222 \\
\hline $\begin{array}{l}\text { Professional } \\
\text { Commitment }\end{array}$ & 0,387 & 4,383 & $\begin{array}{c}0,000 \text { ** } \\
*\end{array}$ & 0,898 & 1,114 \\
\hline Gender & $-0,122$ & $\begin{array}{c}- \\
0,888\end{array}$ & 0,377 & 0,851 & 1,175 \\
\hline Age & 0,026 & 3,306 & $\begin{array}{c}0,001 * * \\
*\end{array}$ & 0,818 & 1,222 \\
\hline F & $8,753 * * *$ & & & & \\
\hline Adj. R2 & 0,362 & & & & \\
\hline
\end{tabular}

\footnotetext{
*** Coefficient is significant at 0.01 ;

** Coefficient is significant at 0.05 ;

* Coefficient is significant at 0.10
}

The table above displays the effect of organizational commitment (affective, continuance, normative, professional commitment) and control variables (gender and age) on the job satisfaction. The sub dimensions of organizational commitment were first included to the model separately. Model 17 was statistically significant $(F=6.339, \mathrm{p}<0.01)$. Also, affective commitment had a statistically significant effect on job satisfaction. But, age and gender did not have the statistically significant effect. Thus, an increase in affective commitment triggers an increase in job satisfaction. Gender did not have a statistically significant impact on the job satisfaction.

Next model (Model 18) shows the effect of affective commitment, gender and age on job satisfaction. The model was statistically significant. $(\mathrm{F}=2.860, \mathrm{p}<0,05) \quad \mathrm{We}$ found that continuance commitment and age had a statistically significant effect on job satisfaction. However, gender did not have a statistically significant impact on the job satisfaction. The model also showed that, when continuance commitment increased, job satisfaction also increased.

Normative commitment, gender and age's effect on the job satisfaction is presented by Model 19 and the mentioned model was found to be statistically significant $(\mathrm{F}=1.645, \mathrm{p}>0.10)$. Age was the only variable that had a statistically significant effect on job satisfaction. Other variables did not have a statistically significant effect on job satisfaction.

After that, we investigated professional commitment and our control variables' effect on the job satisfaction. Model 20 was statistically significant $\quad(\mathrm{F}=8.082, \mathrm{p}<0.01) . \quad$ Professional commitment and age had a statistically significant impact on the job satisfaction. However, gender did not have a statistically significant impact on the job satisfaction.

Organizational commitments' all dimensions were included to Model 21. This model was statistically significant. $(\mathrm{F}=8.753, \mathrm{p}<0.01)$ When the model parameters are observed, it is realized that affective, continuance and professional commitment had a positive and statistically significant effect on the job satisfaction. Normative commitment was also statistically significant but had a negative effect on the job satisfaction. Also, age had a statistically significant impact on the job satisfaction. The most effective variable on the job satisfaction was professional commitment. (B= $0,387)$ The second most effective variable was determined as affective commitment and the third one was continuance commitment. This means that, when professional commitment, affective 
commitment and continuous commitment went up, job satisfaction accordingly went up. The fact that normative commitment had a negative and statistically significant effect on job satisfaction is an unexpected result.

Table 11.The Effect of Mentoring on Job Satisfaction

\begin{tabular}{|c|c|c|c|c|c|}
\hline & \multicolumn{2}{|c|}{$\begin{array}{c}\text { Dependent } \\
\text { variable: } \\
\text { Job } \\
\text { satisfaction }\end{array}$} & & \multicolumn{2}{|c|}{ Collinearity Statistics } \\
\hline $\begin{array}{c}\text { Independent } \\
\text { variables }\end{array}$ & $\beta$ & $\mathbf{t}$ & Sig. & Tolerance & VIF \\
\hline $\begin{array}{c}\text { 22.Career } \\
\text { Development }\end{array}$ & 0.090 & 1.385 & 0.170 & 0.857 & 1.167 \\
\hline Gender & -0.067 & -0.406 & 0.686 & 0.862 & 1.160 \\
\hline Age & 0.019 & 2.273 & 0.026* & 0.919 & 1.088 \\
\hline $\mathrm{F}$ & $2.128 *$ & & & & \\
\hline Adj. R2 & 0.039 & & & & \\
\hline $\begin{array}{c}\text { 23.Role } \\
\text { Modeling }\end{array}$ & 0.138 & 2.344 & $\begin{array}{c}0.022 * \\
*\end{array}$ & 0.927 & 1.079 \\
\hline Gender & -0.085 & -0.539 & 0.591 & 0.903 & 1.107 \\
\hline Age & 0.021 & 2.455 & $\begin{array}{c}0.016 * \\
* *\end{array}$ & 0.944 & 1.059 \\
\hline $\mathrm{F}$ & $3.574 * * *$ & & & & \\
\hline Adj. R2 & 0.085 & & & & \\
\hline $\begin{array}{l}\text { 24.Social } \\
\text { Support }\end{array}$ & 0.089 & 1.352 & 0.180 & 0.931 & 1.074 \\
\hline Gender & -0.049 & -0.301 & 0.764 & 0.897 & 1.115 \\
\hline Age & 0.018 & 2.153 & $\begin{array}{c}0.034 * \\
*\end{array}$ & 0.943 & 1.060 \\
\hline F & $2.096^{*}$ & & & & \\
\hline Adj. R2 & 0.038 & & & & \\
\hline & & & & & \\
\hline
\end{tabular}

\begin{tabular}{|c|c|c|c|c|c|}
\hline $\begin{array}{c}\text { 25.Career } \\
\text { Development }\end{array}$ & -0.081 & -0.678 & 0.500 & 0.250 & 4.006 \\
\hline Role Modeling & 0.225 & 1.990 & $\begin{array}{c}\mathbf{0 . 0 5 0} \\
*\end{array}$ & 0.254 & 3.931 \\
\hline $\begin{array}{c}\text { Social } \\
\text { Support }\end{array}$ & -0.037 & -0.317 & 0.752 & 0.294 & 3.403 \\
\hline Gender & -0.056 & -0.343 & 0.732 & 0.865 & 1.156 \\
\hline Age & 0.020 & 2.288 & $*$ & 0.921 & 1.085 \\
\hline F & $2.283^{* *}$ & & $\mathbf{0 . 0 2 5 *}$ & & \\
\hline Adj. R2 & 0.072 & & & & \\
\hline
\end{tabular}

$* * *$ Coefficient is significant at 0.01 ;

** Coefficient is significant at 0.05 ;

* Coefficient is significant at 0.10

Mentoring is composed of three different dimensions that are career development, role modeling and social support as mentioned previously. Firstly, all these dimensions were included to regression analysis separately. For model 22, we examined the effect of career development and control variables (gender and age) on the job satisfaction. Model 22 was found to be not statistically significant. $(\mathrm{F}=2.128, \mathrm{p}<0.10)$. Age was the only variable that had a statistically significant effect on the job satisfaction. Other variables did not have a statistically significant effect on job satisfaction.

Concerning model 23, the influence of role modeling, gender and age on the job satisfaction was analyzed. Model 23 was determined to be statistically significant $(\mathrm{F}=3.574$, $\mathrm{p}<0.01)$. Role modeling and age had a statistically significant effect on the job satisfaction. Thus, as role modeling and age increased, job satisfaction also increased. The effect of gender on the job satisfaction had a negative beta coefficient, but the effect was not statistically significant.

Impact of Mentoring on Organizational Commitment and Job Satisfaction of Accounting-Finance Academicians Employed in Turkey 
In regards to model 24, social support, gender and age were independent variables and job satisfaction was the dependent variable. The model was not statistically significant $(\mathrm{F}=2.096, \mathrm{p}<0.10)$. Age was the only variable which had a statistically positive effect on the job satisfaction. Other variables did not have a statistically significant effect on the job satisfaction.

Lastly, we examined the effect of career development, role modeling, social support, gender and age on the job satisfaction (Model 25). This model was determined to be statistically significant $(\mathrm{F}=2.283, \mathrm{p}<0.05)$. When model parameters were investigated, only role modeling and age had a statistically significant effect on the job satisfaction. Other variables did not have a statistically significant effect on the job satisfaction.

Table 12.The Effect of Mentoring and Organizational Commitment on Normative Commitment

\begin{tabular}{|c|c|c|c|c|c|}
\hline & \multicolumn{2}{|l|}{$\begin{array}{l}\text { Dependent } \\
\text { variable: } \\
\text { Job } \\
\text { Satisfaction }\end{array}$} & & \multicolumn{2}{|c|}{ Collinearity Statistics } \\
\hline $\begin{array}{c}\text { Independent } \\
\text { variables }\end{array}$ & $\beta$ & $\mathbf{t}$ & Sig. & Tolerance & VIF \\
\hline 26.Gender & -0.073 & -0.470 & 0.640 & 0.864 & 1.157 \\
\hline Age & 0.014 & 1.735 & $0.087 *$ & 0.883 & 1.133 \\
\hline $\begin{array}{c}\text { Career } \\
\text { Development }\end{array}$ & -0.044 & -0.382 & 0.704 & 0.247 & 4.053 \\
\hline Role Modeling & 0.106 & 0.929 & 0.356 & 0.224 & 4.455 \\
\hline Social Support & -0.036 & -0.326 & 0.746 & 0.294 & 3.403 \\
\hline $\begin{array}{c}\text { Affective } \\
\text { Commitment }\end{array}$ & 0.227 & 3.017 & $\begin{array}{c}0.003 * \\
* *\end{array}$ & 0.749 & 1.335 \\
\hline $\mathrm{F}$ & $3.617 * * *$ & & & & \\
\hline Adj. R2 & 0.159 & & & & \\
\hline 27.Gender & -0.105 & -0.640 & 0.524 & 0.826 & 1.211 \\
\hline Age & 0.027 & 2.939 & $\begin{array}{c}\text { 0.004* } \\
* *\end{array}$ & 0.843 & 1.186 \\
\hline
\end{tabular}

\begin{tabular}{|c|c|c|c|c|c|}
\hline $\begin{array}{c}\text { Career } \\
\text { Development }\end{array}$ & -0.068 & -0.561 & 0.576 & 0.247 & 4.053 \\
\hline Role Modeling & .235 & 2.080 & $\begin{array}{c}\text { 0.041* } \\
*\end{array}$ & 0.250 & 4.007 \\
\hline Social Support & 0.077 & -0.660 & 0.511 & 0.293 & 3.411 \\
\hline $\begin{array}{l}\text { Continuance } \\
\text { Commitment }\end{array}$ & 0.137 & 1.521 & 0.132 & 0.809 & 1.236 \\
\hline $\mathrm{F}$ & $2.604 * *$ & & & & \\
\hline Adj. R2 & 0.105 & & & & \\
\hline 28.Gender & -0.037 & -0.225 & 0.823 & 0.833 & 1.201 \\
\hline Age & 0.020 & 2.329 & $\begin{array}{c}\text { 0.022* } \\
*\end{array}$ & 0.908 & 1.101 \\
\hline $\begin{array}{c}\text { Career } \\
\text { Development }\end{array}$ & -0.078 & -0.644 & 0.522 & 0.249 & 4.017 \\
\hline Role Modeling & 0.232 & 2.033 & $0.046 *$ & 0.251 & 3.983 \\
\hline Social Support & -0.033 & -0.283 & 0.778 & 0.293 & 3.414 \\
\hline $\begin{array}{l}\text { Normative } \\
\text { Commitment }\end{array}$ & -0.050 & -0.570 & 0.570 & 0.799 & 1.252 \\
\hline F & $1.940^{*}$ & & & & \\
\hline Adj. R2 & 0.064 & & & & \\
\hline 29.Gender & -0.061 & -0.403 & 0.688 & 0.865 & 1.156 \\
\hline Age & 0.021 & 2.690 & $\begin{array}{c}0.009 * \\
* *\end{array}$ & 0.918 & 1.089 \\
\hline $\begin{array}{c}\text { Career } \\
\text { Development }\end{array}$ & -0.086 & -0.773 & 0.442 & 0.250 & 4.006 \\
\hline Role Modeling & 0.159 & 1.492 & 0.140 & 0.247 & 4.047 \\
\hline Social Support & -0.032 & -0.297 & 0.767 & 0.294 & 3.404 \\
\hline $\begin{array}{l}\text { Professional } \\
\text { Commitment }\end{array}$ & 0.350 & 3.681 & $\begin{array}{c}0.000 * \\
* *\end{array}$ & 0.886 & 1.129 \\
\hline F & $4.466 * * *$ & & & & \\
\hline Adj. R2 & 0.200 & & & & \\
\hline $\begin{array}{c}\text { 30.Career } \\
\text { Development }\end{array}$ & 0,003 & 0,027 & 0,978 & 0,242 & 4,130 \\
\hline Role Modeling & 0,048 & 0,454 & 0,651 & 0,212 & 4,718 \\
\hline Social Support & $-0,065$ & $-0,652$ & 0,517 & 0,293 & 3,415 \\
\hline
\end{tabular}




\begin{tabular}{|c|c|c|c|c|c|}
\hline $\begin{array}{c}\text { Affective } \\
\text { Commitment }\end{array}$ & 0,214 & 3,140 & $\begin{array}{c}\mathbf{0 , 0 0 2 *} \\
* *\end{array}$ & 0,721 & 1,387 \\
\hline $\begin{array}{l}\text { Continuance } \\
\text { commitment }\end{array}$ & 0,216 & 2,646 & $\begin{array}{c}\mathbf{0 , 0 1 0} \\
* *\end{array}$ & 0,724 & 1,381 \\
\hline $\begin{array}{l}\text { Normative } \\
\text { Commitment }\end{array}$ & $-0,125$ & $-1,652$ & $0,103 *$ & 0,758 & 1,320 \\
\hline $\begin{array}{l}\text { Professional } \\
\text { Commitment }\end{array}$ & 0,384 & 4,116 & $\begin{array}{c}\mathbf{0 , 0 0 0} * \\
* *\end{array}$ & 0,832 & 1,202 \\
\hline Gender & $-0,117$ & $-0,817$ & 0,417 & 0,801 & 1,248 \\
\hline Age & 0,026 & 3,199 & $\begin{array}{c}\mathbf{0 , 0 0 2} \\
* *\end{array}$ & 0,774 & 1,291 \\
\hline F & $5,696^{* * *}$ & & & & \\
\hline Adj. R2 & 0,340 & & & & \\
\hline \multicolumn{6}{|c|}{$* * *$ Coefficient is significant at 0.01} \\
\hline \multicolumn{6}{|c|}{$* *$ Coefficient is significant at 0.05} \\
\hline \multicolumn{6}{|c|}{ * Coefficient is significant at 0.10} \\
\hline
\end{tabular}

The table above shows the effect of mentoring (career development, role modeling, and social support), gender, age and affective commitment on the job satisfaction. We did add affective commitment to the model. Model 26 was found to be statistically significant ( $F=$ 3.617,p<0,01). The effect of age and affective commitment on the job satisfaction was positive and statistically significant. Career development, role modeling, social support and age did not have a statistically significant effect.

Then, we added continuance commitment to the model besides affective commitment for model 27. This model was found to be statistically significant $(\mathrm{F}=2.604, \mathrm{p}<0.05)$. Result of the regression analysis showed that, age and role modeling had a positive and statistically significant effect on job satisfaction. Other variables did not have a statistically significant effect on the job satisfaction.

Concerning model 28, the influence of career development, role modeling, social support, normative commitment, gender and age on the job satisfaction was analyzed. Model 28 was determined to be statistically significant $(\mathrm{F}=1.940$; $\mathrm{p}<0.10)$ When model parameters were investigated, role modeling and age had a statistically significant effect on the job satisfaction. Other variables did not have a statistically significant effect on the job satisfaction.

Model 29 shows the effect of career development, role modeling, gender, age and professional commitment on the job satisfaction. Model 29 was statistically significant. ( $\mathrm{F}=4.466$; $\mathrm{p}<0.0$ ). The effect of age and professional commitment on the job satisfaction was positive and statistically significant. Other variables did not have a statistically significant effect on the job satisfaction.

Concerning the last model (Model 30), we investigated the impact of mentoring's all variables (career development, role modeling, and social support), organizational commitment (affective commitment, continuance commitment, normative and professional commitment) and control variables (gender and age) on the job satisfaction. This model was statistically significant $(\mathrm{F}=5.696, \mathrm{p}<0.01)$. Results of the regression analysis reveal that, mentoring did not have a statistically significant effect on job satisfaction. In other words, no dimensions of mentoring had a significant effect on job satisfaction. However, organizational commitment's all variables had a statistically significant effect on the job satisfaction. Also, affective commitment, continuance commitment and professional commitment had a positive effect on job satisfaction while normative commitment had a negative effect on job satisfaction. Finally, it is determined that age had a positive and statistically significant effect on the job satisfaction.

\section{Conclusion and Results}

Study revealed several important results. First of all, according to the correlation analysis, career development, role modeling, social support, affective commitment, normative commitment and professional commitment were positively linked to each other. Also, social support

Impact of Mentoring on Organizational Commitment and Job Satisfaction of Accounting-Finance Academicians Employed in Turkey 
and professional commitment were positively correlated with job satisfaction. Moreover, career development, role modeling, social support, continuance commitment and normative commitment were determined to not have a relationship with job satisfaction.

Regression analysis of the research also presented significant results. It is found that career development and age have a statistically significant effect on the affective commitment. Furthermore, role modeling had a positive and statistically significant effect on affective commitment. An increase in role modeling did lead to an increase in affective commitment. However, gender and age did not have a statistically significant effect on affective commitment. Then, study indicated that social support had a positive and statistically significant effect on the affective commitment. But, gender and age did not have a statistically significant effect on the affective commitment.

Another eye-catching result of the research was that, when all variables which are career development, role modeling, social support, gender and age were included to the model together, only role modeling had a positive and statistically significant effect on the affective commitment. Career development, social support, gender and age did not have a statistically significant effect on the affective commitment. This proved that, when variables were included to the model altogether, they did shadow each others' effect.

Besides, regression analysis reflected that, gender had a positive and statistically significant effect while age had a negative statistically significant effect on continuance commitment. Thus, when age went up, continuance commitment went down. Also, research revealed that female academicians had a higher continuance commitment. But, career development did not have a statistically significant effect on continuance commitment.

Then, research shows that gender had a positive and statistically significant effect on continuance commitment while age had a negative and statistically significant effect on the continuance commitment. But, social support did not have statistically significant effect on the continuance commitment. Then, findings indicate that, gender and age had a statistically significant effect on continuance commitment. However, gender had a positive effect while age had a negative effect on the continuance commitment Moreover, social support did not have a statistically significant effect on the continuance commitment.

When the impact of mentoring's all variables (career development, role modeling, and social support) and effect of control variables (gender and age) on the continuance commitment were analyzed, the model was statistically significant. Gender and age had a statistically significant effect on continuance commitment. On the other hand, no dimension of mentoring had an effect on continuance commitment. Thus, when variables were included to the model separately, their effect was statistically significant. However, when all variables were included to the model altogether, their effect did not exist on the dependent variables. This means that variables shadow each other's impact.

Furthermore, finding of the research present that, career development and gender were statistically significant on the normative commitment. Additionally, female academicians had a higher normative commitment. Age did not have a statistically significant effect on the normative commitment. Also, the effect of role modeling, gender and age on the normative commitment is statistically significant according to the research. Similarly, role modeling and gender has a positive and statistically significant effect on the normative commitment. The same cannot be said for age, since its effect on the normative commitment is not statistically significant.

Next, impact of social support, gender and age on the normative commitment is statistically significant. Likewise, social support and gender had a positive and statistically significant effect on normative commitment. But, age did not have the significant effect on normative commitment. When the multiple effect of career development, role modeling, and social support on normative commitment was analyzed, it was found to be statistically significant. The result of the multiple 
regression analysis showed that, when variables were included to the model altogether, their effect did no longer exist. Gender was the only variable that had a statistically significant effect on normative commitment.

Additionally, research revealed results about the effect of mentoring (career development, role modeling, and social support), gender and age on the professional commitment. Career development, gender and age's impact on the professional commitment was found to be statistically significant. Also, the effect of career development on the professional commitment was positive and statistically significant. Gender and age had a negative but statistically insignificant effect on the professional commitment.

Besides, the effect of role modeling, gender and age on professional commitment and the impact of social support, gender and age on the professional commitment were found to be statistically Role modeling and social support had a positive statistically significant effect on professional commitment. Gender and age did possess negative but statistically insignificant impact on the professional commitment. Multiple regression analysis reflected that no variable had a statistically significant effect on the professional commitment. Also, the multiple effect of mentoring variables (career development, role modeling, and social support) on professional commitment was found to be statistically significant. The results of multiple regression analysis signal that when variables are included to the model altogether, their effect no longer exists. This is because variables shadow each other's impact.

In addition, research determined that effect of organizational commitment (affective, continuance, normative, professional commitment) and control variables (gender and age) on the job satisfaction was statistically significant. Also, affective commitment had a statistically significant effect on job satisfaction. But, the same is not true for age and gender's effect on job satisfaction. Likewise, gender did also not have a statistically significant impact on the job satisfaction.
Plus, the effect of affective commitment, gender and age on job satisfaction was found to be statistically significant. Also, continuance commitment and age had a statistically significant effect on job satisfaction. However, gender did not have a statistically significant impact on the job satisfaction. Then, it was found that age was the only variable that had a statistically significant effect on job satisfaction. Gender and normative commitment did not have a statistically significant effect on job satisfaction. Following this, professional commitment and control variables' effect on the job satisfaction was investigated. Model was statistically significant and professional commitment as well as age had a statistically significant impact on the job satisfaction. However, gender did not have a statistically significant impact on the job satisfaction.

Also, research pointed out that affective, continuance and professional commitment had a positive and statistically significant effect on the job satisfaction. Normative commitment was also statistically significant but had a negative effect on the job satisfaction. Also, age had a statistically significant impact on the job satisfaction. The most effective variable on the job satisfaction was professional commitment. The second most effective variable was determined as affective commitment and the third one was continuance commitment. Normative commitment having a negative and statistically significant effect on job satisfaction was an unexpected result.

In the next step, effect of career development and control variables (gender and age) on the job satisfaction was examined. It was realized that the impact was not statistically significant. Age was the only variable that had a statistically significant effect on the job satisfaction. The influence of role modeling, gender and age on the job satisfaction was alo analyzed and determined to be statistically significant. Role modeling and age had a statistically significant effect on the job satisfaction. The effect of gender on the job satisfaction had a negative beta coefficient, but the effect was not statistically significant.

Impact of Mentoring on Organizational Commitment and Job Satisfaction of Accounting-Finance Academicians Employed in Turkey 
Then, impact of social support, gender and age on job satisfaction was found to be not statistically significant. Age was the only variable which had a statistically positive effect on the job satisfaction. Also, role modeling and age had a statistically significant effect on the job satisfaction. Social support and gender did not have a statistically significant effect on the job satisfaction.

Furthermore, it was realized that the effect of age and affective commitment on the job satisfaction was positive and statistically significant. But career development, role modeling, social support and age did not have a statistically significant effect. Then, result of the regression analysis showed that, age and role modeling had a positive and statistically significant effect on job satisfaction.

Moreover, the influence of career development, role modeling, social support, normative commitment, gender and age on the job satisfaction was analyzed and model was determined to be statistically significant. Role modeling and age had a statistically significant effect on the job satisfaction while other variables did not have a statistically significant effect on the job satisfaction.

After that, the effect of career development, role modeling, gender, age and professional commitment on the job satisfaction was checked and model was statistically significant. The effect of age and professional commitment on the job satisfaction was positive and statistically significant, but the same was not determined for other variables.

Finally, the impact of mentoring's all variables (career development, role modeling, and social support), organizational commitment (affective commitment, continuance commitment, normative and professional commitment) and control variables (gender and age) on the job satisfaction was analyzed. The model was statistically significant and results of the regression analysis revealed that, mentoring did not have a statistically significant effect on job satisfaction. This means that, no dimensions of mentoring had a significant effect on job satisfaction. But, organizational commitment's all variables had a statistically significant effect on the job satisfaction. Also, affective commitment, continuance commitment and professional commitment were identified to have a positive effect on the job satisfaction while normative commitment had a negative effect on job satisfaction. Consequently, age had a positive and statistically significant effect on the job satisfaction.

\section{Limitations and Recommendations for Future Research}

Research was subject to specific limitations. Although the accounting and finance groups which were informed of our study were very supportive, academicians' participation in the questionnaire was lower than expected. It is believed that the heavy workload, administrative duties and other responsibilities of academicians were influential at this point, since completing the survey requires some time and effort. Thus, the emphasized situation caused the sample of research to be limited. It is advised for future researchers that, they analyze a larger sample, especially considering the fact that number of Turkish public and private universities have increased seriously in the recent years 


\section{References}

Allen Natalie and John Meyer (1990). "The Measurement and Antecedents of Affective. Continuance. and Normative Commitment to the Organization". Journal of Occupational Psychology. Vol. 63. pp. 1-18.

Allen Tammy, Mark Poteet, Lillian Eby, Elizabeth Lentz and Lizzette Lima (2004). "Career Benefits Associated with Mentoring for Protégés: A Meta Analysis". Journal of Applied Psychology. Vol. 89. No: 1. p. 127.

Allen Tammy, Stacy McManus and Joyce Russell (1999). "Newcomer Socialization and Stress: Formal Peer Relationships as a Source of Support". Journal of Vocational Behavior. Vol. 54. pp. 453-470.

Aranya Nissim and Kenneth Ferris (1984). "A Reexamination of Accountants' OrganizationalProfessional Conflict". The Accounting Review. Vol. 59. No: 1. pp. 1-15.

Aryee Samuel, Yue Wah Chay and Juniper Chew (1996). "The Motivation to Mentor among Managerial Employees". Group and Organization Management. Vol. 21. pp. 261-277.

Aydin Serkan, Ayse Tansel Cetin and Gokhan Ozer (2007). "The relationship between marketing and product development process and their effects on firm performance". Academy of Marketing Studies Journal. Vol.11. No:1.

Barker Patricia, Kathy Monks and Finian Buckley (1999). "The Role of Mentoring in the Career Progression of Chartered Accountants". British Accounting Review. Vol. 31. pp. 297-312.
Bateman Thomas and Stephen Strasser (1984). "Longitudinal Analysis of the Antecedents of Organizational Commitment". Academy of Management Journal. Vol. 27. pp. 95- 112.

Baugh Gayle, Melenie Lankau and Terri Scandura (1996). "An Investigation of the Effects of Protégé Gender on Responses to Mentoring”. Journal of Vocational Behavior. Vol. 49. pp. 309323.

Bernstein Beverly and Beverly Kaye (1986). "Teacher. Tutor. Colleague and Coach". Personnel Journal. Vol. 65. pp. 44-51.

Blackburn Robert, David Chapman and Susan Cameron (1981). "Cloning in Academe: Mentorship and Academic Careers", Research in Higher Education, Vol. 15, No: 4, pp. 315-327.

Blau, Francine, Janet Currie, Rachel Croson and Donna Ginther (2010). "Can Mentoring Help Female Assistant Professors? Interim Results from a Randomized Trial", NBER Working Paper, No: w15707.

Bozionelos Nikos (2004). "Mentoring Provided: Relation to Mentor's Career Success. Personality and Mentoring Received". Journal of Vocational Behavior. Vol. 64. No: 1. p. 25.

Brashear Thomas, Chris Manolis and Charles Brooks (2005). "The Effects of Control. Trust. and Justice on Salesperson Turnover". Journal of Business Research. Vol. 58. pp. 241-249.

Impact of Mentoring on Organizational Commitment and Job Satisfaction of Accounting-Finance Academicians Employed in Turkey 
Chao Georgia, Pat Walz and Phil Gardner (1992). "Formal and Informal Mentorships: A Comparison on Mentoring Functions and Contrast with Nonmentored Counterparts". Personnel Psychology. Vol. 45. pp. 619-636.

Colarelli Stephen and Ronald Bishop (1990). "Career Commitment: Functions. Correlates. and Management". Group \& Organization Studies. Vol. 15. pp. 158-176.

Covaleski Mark, Mark Dirsmith, James Heian and Sajay Samuel (1998). "The Calculated and the Avowed: Techniques of Discipline and Struggles over Identity in Big Six Public Accounting Firms". Administrative Science Quarterly. Vol. 43. pp. 293-327.

Curry James, Douglas Wakefield and Charles Mueller (1986). "On the Causal Ordering of Job Satisfaction and Organizational Commitrnent". Academy of Management Journal. Vol. 29. pp. 847-858.

Çavuş Şenol and Arzu Gürdoğan (2008). “Örgüt Kültürü ve Örgütsel Bağlılık İlişkisi: Beş Yıldızlı Bir Otel İşletmesinde Araştırma”. Ticaret ve Turizm Eğitim Fakültesi Dergisi. No: 1. pp. 1834.

Dalton. Gene, Paul Thompson and Raymond Price (1977). "The Four Stages of Professionals' Careers- A New Look at Performance of Professionals". Journal of Organizational Dynamics. Summer Issue. pp. 1942.

Dirsmith Mark, Mark Covaleski and James Heian (1997). "Structure and Agency in an Institutionalized Setting: The Application and Social Transformation of Control in the Big Six". Journal of Accounting. Organizations and Society. Vol. 22. p. 15.
Dreher George and Ronald Ash (1990). “A Comparative Study of Mentoring among Men and Women in Managerial. Professional and Technical positions". Journal of Applied Psychology. Vol. 75. pp. 539-546.

Ehlen Craig and Robert Welker (1996). "Procedural Fairness in the Peer and Quality Review Programs". Auditing: A Journal of Practice and Theory. Vol. 15. pp. 38-52.

Fagenson Ellen (1989). "The Mentor Advantage: Perceived Career/Job Experiences of Prote'ge's Versus Non-Prote'ge's". Journal of Organizational Behavior. Vol. 10. pp. 309-320.

Farkas Arthur and Lois Tetrick (1989). “A Three-Wave Longitudinal Analysis of the Causal Ordering of Satisfaction and Commitment on Turnover Decisions". Journal of Applied Psychology. Vol. 74. pp. 855-868.

Hackett Rick, Peter Bycio and Peter Hausdorf (1992). "Further Assessment of a ThreeComponent Model of Organizational Commitment". Academy of Management Best Paper Proceedings. pp. 212-216.

Hackman Richard and Greg Oldham (1976). "Motivation through the Design of Work: Test of a Theory". Journal of Organizational Behavior and Human Performance. Vol. 35. pp. 250-279.

Hair Joseph, Rolph Anderson, Ronald Tatham and William Black (1998). "Multivariate data analysis with Readings". Prentice Hall. New Jersey.

Hall. Douglas (1976). "Careers in Organizations". Scott. Foresman Series in Management and Organizations. p. 1-236. 
Heimann. Beverly and Khushwant Pittenger (1996). "The Impact of Formal Mentorship on Socialization and Commitment of Newcomers". Journal of Managerial Issues. Vol. 8. No: 1. pp. 108-117.

Higgins Monica and Kathy Kram (2001). "Reconceptualizing Mentoring at Work: A Developmental Network Perspective". Academy of Management Review. Vol. 26. pp. 264-288.

Kanter Rosabeth Moss (1993). "Men and Women in the Corporation". Basic Books Publishing. $2^{\text {nd }}$ Edition. New York. USA. pp. 1416.

Kim Moon-Koo, Myeong-Cheol Park and Dong-Heon Jeong (2004). "The effects of customer satisfaction and switching barrier on customer loyalty in Korean Mobile Telecommunication Services". Telecommunications Policy. Vol. 28. No: 2. pp.145-159.

Koberg Christine, Wayne Boss and Eric Goodman (1998). "Factors and Outcomes associated with Mentoring among Health-Care Professionals". Journal of Vocational Behavior. Vol. 53. pp. 58-72.

Kram Kathy (1988). "Mentoring at Work: Developmental Relationships in Organizational Life". University Press of America. p. 1-268.

Levinson Daniel, Charlotte Darrow. Edward Klein. Maria Levinson and Braxton McKee (1978). "Seasons of a Man's Life". Knopf Publishing. New York. USA. p. 1-363.

Libby Theresa (1999). "The Influence of Voice and Explanation on Performance in Participative Budgeting Setting". Journal of Accounting. Organizations and Society. Vol. 24. pp. 125-138. .
Lind Allen, Robin Lissak and Henry Mendes (1983). "Organizational and NonOrganizational Influences on Attitudes towards Work". University of Illinois at Urbana Publications. p. 6.

Lind Allan and Tom Tyler (1988). "The Social Psychology of Procedural Justice”. Plenum Press. New York. pp. 1-241

Lindquist Tim (1995). "Fairness as an Antecedent to Participative Budgeting: Examining the Effect of Distributive Justice. Procedural justice and Referent Cognitions on Satisfaction and Performance". Journal of Management Accounting Research. Vol. 7. pp. 122-147.

Major Debra, Steve Kozlowski, Georgia Chao and Phil Gardner (1995). “A Longitudinal Investigation of Newcomer Expectations. Early Socialization Outcomes and the Moderating Effects of Role Development Factors". Journal of Applied Psychology. Vol. 80. pp. 418-431.

Masterson Suzanne, Kyle Lewis, Barry Goldman and Susan Taylor (2000). "Integrating Justice and Social Exchange: The Differing Effects of Fair Procedures and Treatment on Work Relationships". Academy of Management Journal. Vol. 45. pp. 738-748.

McFarlin Dean and Paul Sweeney (1992). "Distributive and Procedural Justice as Predictors of Satisfaction with Personal and Organizational Outcomes". Academy of Management Journal. Vol. 35. No: 3. pp. 626-637.

McPhail Janelle and Ronel Erwee (2000). "Developing Professional Relationships Between Supervisors and Doctoral Candidates", Australian Journal of Management and Organisational Behaviour, Vol.3, No:1, p.76.

Impact of Mentoring on Organizational Commitment and Job Satisfaction of Accounting-Finance Academicians Employed in Turkey 
Megginson David and David Clutterbuck (1995). "Mentoring in Action". Kogan Page Publishing. London. United Kingdom. p. 5.

Meyer John, Natalie Allen and Catherine Smith (1993). "Commitment to Organizations and Occupations: Extension and Test of a ThreeComponent Conceptualization". Journal of Applied Psychology. Vol. 78. pp. 538-551.

Mullen Ellen (1994). "Framing the Mentoring Relationship in an Information Exchange". Human Resource Management Review. Vol. 4. pp. 257-281.

Muschallik, Julia and Kerstin Pull (2012). "Mentoring in Higher Education: Does it Enhance Mentees' Research Productivity?", SSRN Working Paper, No: 2067003.

Neumark David and Rosella Gardecki (1996). "Women Helping Women? Role-Model and Mentoring Effects on Female Ph.D. Student in Economics", NBER Working Papers, No: w5733.

Noe Raymond (1988). “An Investigation of the Determinants of Successful Assigned Mentoring Relationships". Journal of Personnel Psychology. Vol. 41. pp. 457-479.

Norusis Marija (1993). "SPSS for Windows: Base System User's Guide". Release 6.0. SPSS Inc. Chicago.

Nunnally Jum (1978). "Psychometric theory", McGraw-Hill Publishing. 2nd Edition. New York.
Orpen Christopher (1997). "The Effects of Formal Mentoring on Employee Work Motivation. Organizational Commitment and Job Performance". Journal of Learning Organization. Vol. 4. Issue: 2. pp. 53-60.

Ostroff Cheri and Steve Kozlowski (1993). "The Role of Mentoring in the Information Gathering Processes of Newcomers during Early Organizational Socialization". Journal of Vocational Behavior. Vol. 42. pp. 170-183.

Özer Gökhan and Mehmet Günlük (2010). "The Effects of Discrimination Perception on Turkish Public Accountants". African Journal of Business Management. Vol. 4. No: 8. pp. 15001509.

Özkalp Enver, Çiğdem Kırel, Zerrin Sungur and Aytül Ayşe Cengiz (2006). "The Importance of Mentoring on Organizational Socialization of the Research Assistants in Anadolu University", Sosyal Bilimler Dergisi (Journal of Social Science), Issue: 2, pp. 55-70.

Öztürk Veli, Seyhan Çil Koçyiğit and Emine Çına Bal (2011). "Muhasebe Meslek Mensuplarının Mesleki Tükenmişlik Düzeyleri ile İşe Bağlılık Arasındaki İlişkiyi Belirlemeye Yönelik Bir Araştırma: Ankara İli Örneği’. Doğuş Üniversitesi Dergisi. Vol. 12. No: 1. pp. 84-98.

Pasework William and Ralph Viator (2006). "Sources of Work-Family Conflict in the Accounting Profession". Journal of Behavioral Research in Accounting. Vol 18. pp. 147-165.

Ragins Belle Rose and John Cotton (1999). "Mentor Functions and Outcomes: A Comparison of Men and Women in Formal and Informal Mentoring Relationships". Journal of Applied Psychology. Vol. 84. pp. 529-550. 
Ragins Belle Rose, John Cotton and Janice Miller (2000). "Marginal Mentoring: The Effects of Type of Mentor. Quality of Relationship. and Program Design on Work and Career Attitudes". Academy of Management Journal. Vol. 43. pp. 1177-1194.

Ragins Belle Rose and Terri Scandura (1994). "Gender Differences in Expected Outcomes of Mentoring Relationships". Academy of Management Journal. Vol. 37. pp. 957-971.

Rasch Ronald and Adrian Harrell (1990). "The Impact of Personal Characteristics on the Turnover Behavior of Accounting Professionals". Auditing: A Journal of Practice and Theory. Vol. 9. No: 2. pp. 90-102.

Roberts James, Kevin Coulson and Lawrence Chonko (1999). "Salesperson Perceptions of Equity and Justice and Their Impact on Organizational Commitment and Intent to Turnover". Journal of Marketing Theory and Practice. Vol. 7. No: 1. pp. 1-16.

Roche Gerard (1979). "Much Ado about Mentors". Harvard Business Review. Vol. 57. pp. $14-28$.

Rockoff Jonah (2008). "Does Mentoring Reduce Turnover and Improve Skills of New Employees? Evidence from Teachers in New York City", NBER Working Papers, No: 13868.

Sawyer John (1992). "Goal and Process Clarity: Specification of Multiple Constructs of Role Ambiguity and a Structural Equation Model of their Antecedents and Consequences". Journal of Applied Psychology. Vol. 77. pp. 130-142.
Scandura Terri (1997). "Mentoring and Organizational Justice: An Empirical Investigation". Journal of Vocational Behavior. Vol. 51. p. 58. 65.

Seibert Scott (1999). "The Effectiveness of Facilitated Mentoring: A Longitudinal QuasiExperiment". Journal of Vocational Behavior. Vol. 54. pp. 483-502.

Sheldon Alexander and Marian Ruderman (1987). "The Role of Procedural and Distributive Justice in Organizational Behavior". Social Justice Research. Vol.1. No: 2. pp. 177-198.

Siegel Philip and Khursheed Omer (1995). "Mentoring as an Antidote to Stress during a Regional CPA Firm Merger". Journal of Business and Entrepreneurship. Vol. 7. pp. 87-100.

Siegel Philip, Alan Reinstein and Cathleen Miller (2001). "Mentoring and Organizational Justice among Audit Professionals". Journal of Accounting. Auditing and Finance. Vol. 16. No: 1. pp. 1-25.

Silverhart Todd (1994). "It Works: Mentoring Drives Productivity Higher". Managers Magazine. pp. 14-15.

Sweeney Paul and Dean McFarlin (1993). "Workers' Evaluations of the 'Ends' and the 'Means': An Examination of Four Models of Distributive and Procedural Justice". Organizational Behavior and Human Decision Processes. Vol. 55. pp. 23-40.

Impact of Mentoring on Organizational Commitment and Job Satisfaction of Accounting-Finance Academicians Employed in Turkey 
Tansel Cetin Ayse, Mine Aksu and Gokhan Ozer (2012). "Technology investments, performance and the effects of size and region in Turkish hospitals". The Service Industries Journal, Vol.32, No:5, pp:747-771.

Tharenou Phyllis (2005). "Does Mentor Support Increase Women's Career Advancement More Than Men's? The Differential Effects of Career and Psychosocial Support", Australian Journal of Management, Vol. 30, No:1. pp. 77-109.

Turban Daniel. and Thomas Dougherty (1994). "Role of Protégé Personality in Receipt of Mentoring and Career Success". Academy of Management Journal. Vol. 37. pp. 688-702.

Viator Ralph (2001). "An examination of African Americans' access to public accounting mentors: perceived barriers and intentions to leave". Accounting, Organizations and Society Journal. Vol. 26. pp. 541-561.

Viator Ralph and William Pasework (2005). "Mentorship Separation Tension in the Accounting Profession: The Consequences of Delayed Structural Separation”. Accounting, Organizations and Society Journal. Vol. 30. pp.371-387.
Whitely William and Pol Coetsier (1993). "The Relationship of Career Mentoring to Early Career Outcomes". Organization Studies. Vol. 14. pp. 419-441.

Whitely William, Thomas Dougherty and George Dreher (1991). "Relationship of Career Mentoring and Socioeconomic Origin to Managers' and Professionals' Early Career Progress". Academy of Management Journal. Vol. 34. pp. 331-351.

Wickman Floyd (1997). "Mentoring”. Publications of Irwin Professional Group. New York. USA. pp. 1-191.

Wilson James and Nancy Elman (1990). "Organizational Benefits of Mentoring". Academy of Management Executive. Vol. 4. pp. 88-94.

Yüceler Aydan (2009). “Örgütsel Bağl1lık ve Örgüt İklimi İlişkisi: Teorik ve Uygulamalı Bir Çalışma". Selçuk Üniversitesi Sosyal Bilimler Enstitüsü Dergisi. No: 2. pp. 445-458.

Zey Michael (1984). "The Mentor Connection: Strategic Alliances in Corporate Life". Dow-Jones Irwin Publishing. New Jersey. USA. p. $1-228$. 